\title{
BROOKHAVEN NATIONAL LABORATORY GROUNDWATER PROTECTION MANAGEMENT PROGRAM DESCRIPTION
}

May 31, 2002

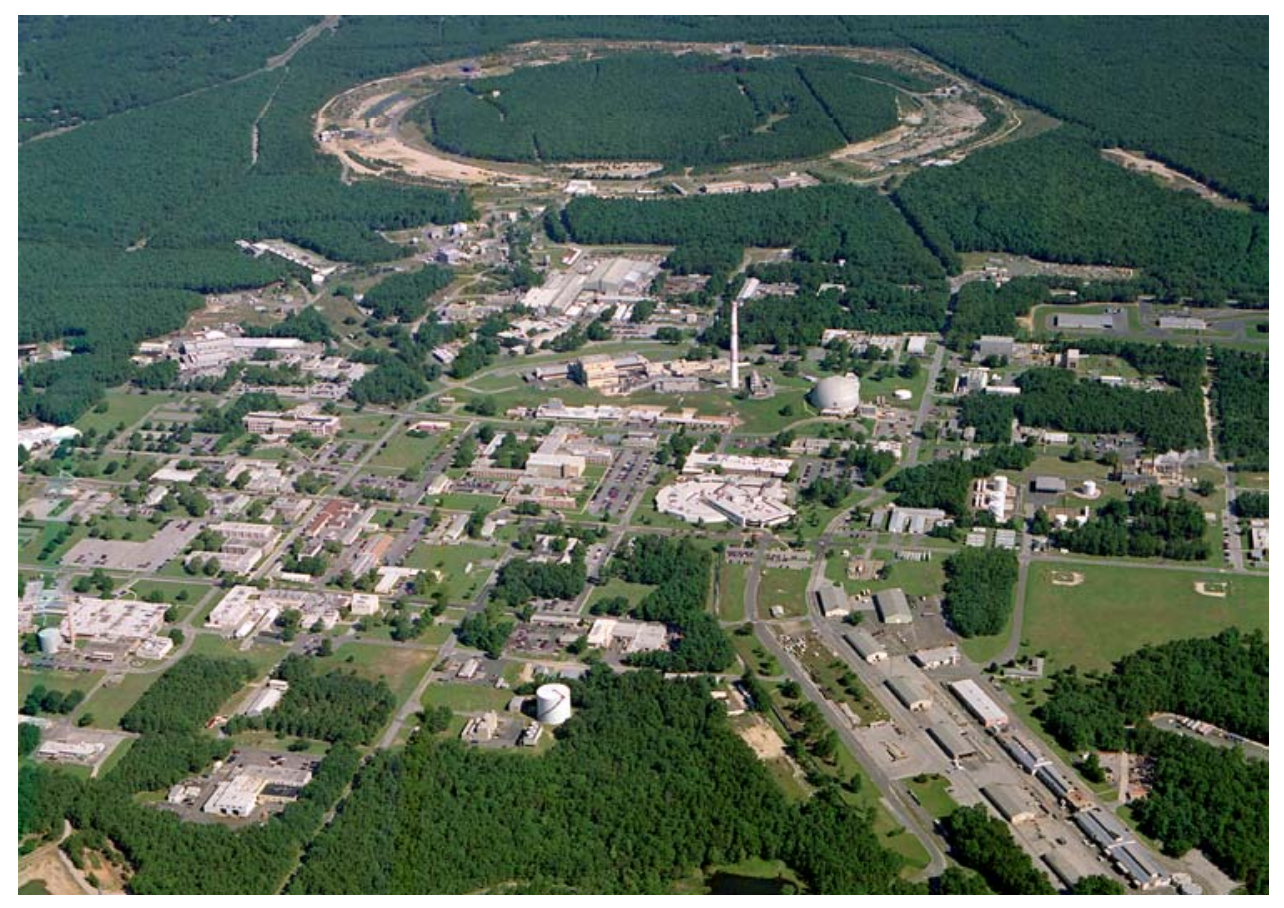

\section{BROOKHOVEN}

NATIONAL LABORATORY

Brookhaven National Laboratory

Brookhaven Science Associates

Upton, New York 11973-5000

Under Contract No. DE-AC02-98CH10886 with the

United States Department of Energy 
BNL - 52664

Formal Report

\section{BROOKHAVEN NATIONAL LABORATORY GROUNDWATER PROTECTION MANAGEMENT PROGRAM DESCRIPTION}

May 31, 2002

Prepared by:

Douglas E. Paquette, PG

Drew B. Bennett, PE

William R. Dorsch

Environmental Services Division

Brookhaven National Laboratory

Contributions and peer review were provided by:

George A. Goode, Robert J. Lee, and Keith Klaus

BNL Environmental Services Division

Robert F. Howe

BNL Environmental Management Directorate

Kathy Geiger

BNL Community, Education, Government \& Public Affairs

Brookhaven Science Associates

Brookhaven National Laboratory

Upton, New York 11973-5000 


\title{
Brookhaven National Laboratory Groundwater Protection Management Program Description
}

\author{
Executive Summary
}

The Department of Energy Order 5400.1, “General Environmental Protection Program” requires development and implementation of a groundwater protection program. The primary goal of this document, the Groundwater Protection Management Program (GPMP) description, is to ensure that plans for groundwater protection, management, monitoring and restoration are fully defined, integrated and managed in a cost-effective manner that is consistent with federal, state and local regulations.

The Brookhaven National Laboratory (BNL) GPMP includes policy, strategy, requirements and regulations applicable to groundwater protection, and an overview of groundwater resources. The BNL GPMP consists of four main elements: 1) prevention; 2) monitoring; 3) restoration; and 4) communication.

Prevention: BNL has completed a three-phased project to: 1) identify past or current activities with the potential to impact environmental quality; 2) conduct a BNL-wide review of all experiments and industrial-type operations to determine the potential impacts of those activities on the environment and integrate pollution prevention/waste minimization, resource conservation, and compliance into planning, decision-making and implementation; and 3) develop and implement an Environmental Management System to manage future changes in activities and strive for continual improvement. These activities are designed to prevent further pollution of the sole source aquifer underlying the BNL site.

Monitoring: BNL has an extensive and coordinated groundwater monitoring network designed to evaluate progress in the cleanup of groundwater contamination from historical waste operations and to verify that engineered and operational controls of existing threats to groundwater are working as planned. The Environmental Services Division coordinates groundwater monitoring programs for the Environmental Management Directorate, which has been tasked with implementing remedial actions to cleanup the groundwater under the Comprehensive Environmental Response, Compensation, and Liability Act, and for active research and support facilities. Data Quality Objectives, plans and procedures, sampling and analysis, quality assurance, data management, and well installation, maintenance and abandonment programs have been integrated to "optimize" the groundwater monitoring system.

Restoration: BNL was added to the National Priorities List in 1989. Thirty Areas of Concern have been grouped into six Operable Units. Remedial Investigation/Feasibility Studies have been conducted for each Operable Unit. A primary goal of the Environmental Restoration program is remediating soil and groundwater contamination, and preventing additional groundwater contamination from migrating off-site. To that end, contaminant sources (e.g., contaminated soil, underground tanks, etc.) are being removed or remediated to prevent further contamination of groundwater. Records of Decisions (RODs) have been reached with the regulatory agencies on groundwater cleanup issues. The goals of the program are to prevent or minimize plume growth, and to restore the groundwater quality to drinking water standards within 30 years in the Upper Glacial aquifer.

Communication: BNL has a community involvement, government and public affairs program to ensure that BNL communicates with the community in a consistent, timely and accurate manner. A number of communication mechanisms are in place, such as web pages, mailings, briefings and roundtables. Technical reports summarizing data, evaluations, and program indices are prepared annually. A Groundwater Protection Contingency Plan has also been developed as a lab-wide procedure to guide technical action and communication with Laboratory management and stakeholders in the event of off-normal groundwater data. 


\section{Brookhaven National Laboratory Groundwater Protection Management Program Description \\ Table of Contents}

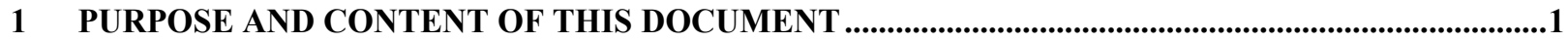

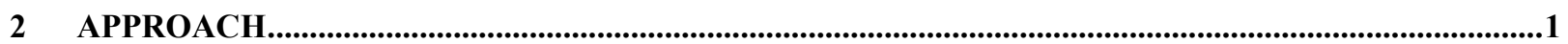

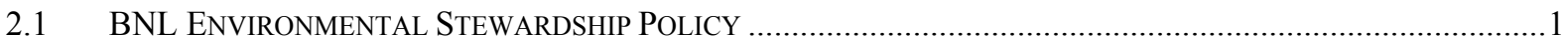

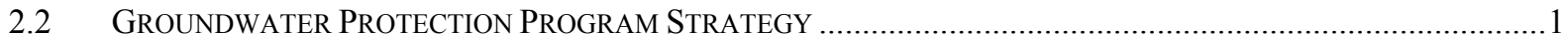

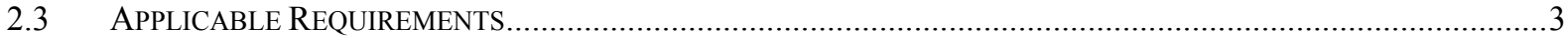

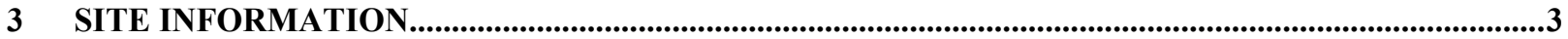

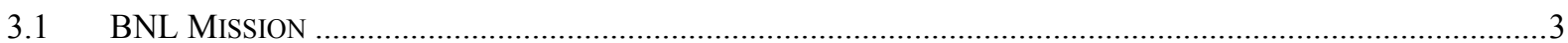

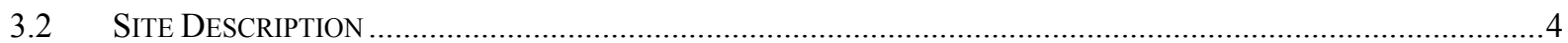

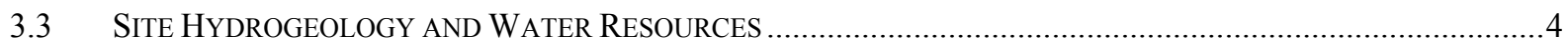

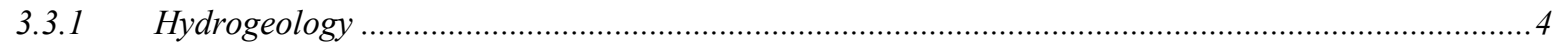

3.3.1.1 Upper Pleistocene Deposits/Upper Glacial Aquifer ...................................................................................

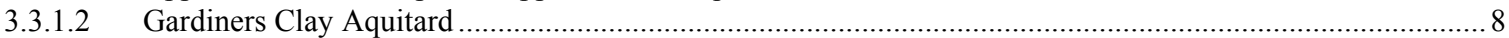

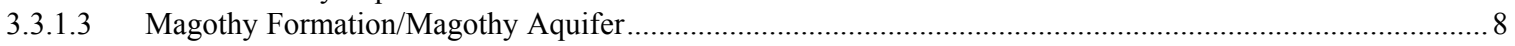

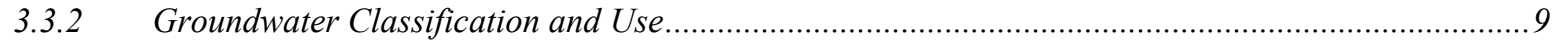

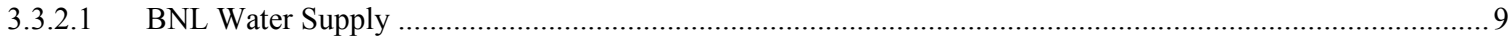

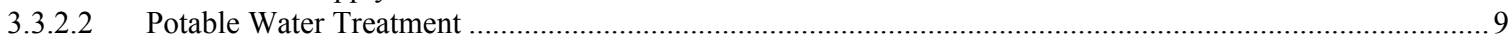

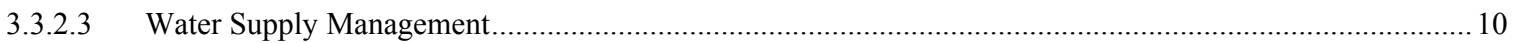

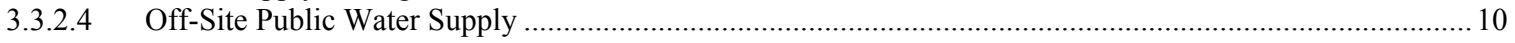

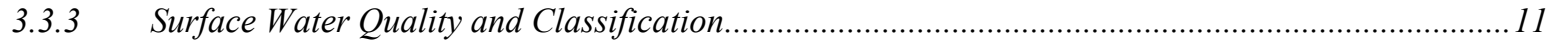

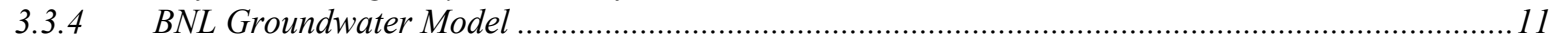

3.3.5 Groundwater Resource Vulnerability Assessment .......................................................................... 12

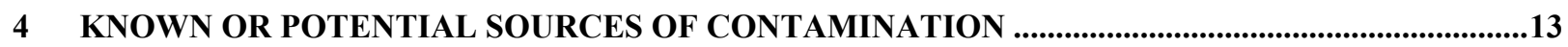

4.1 CERCLA AREAS OF CONCERN/OPERABLE UNITS.................................................................................13

4.2 Groundwater Quality NEAR ACTIVE RESEARCH AND SUPPORT FACILITIES (NON-CERCLA)..............15

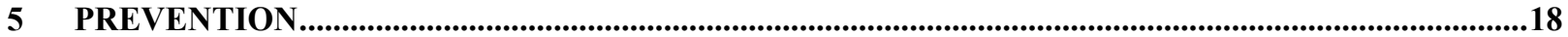

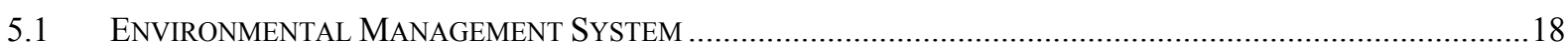

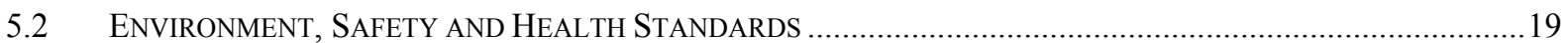

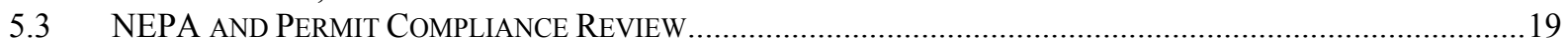

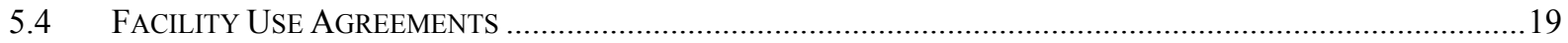

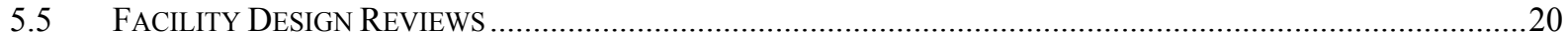

5.6 PROCESS REVIEW (ROUTINE PROCESSES AND EXPERIMENTS) …….....................................................20

5.7 POLLUTION PREVENTION AND WASTE MinIMIZATION OPPORTUNITIES ASSESSMENTS AND PROGRAMS ....21

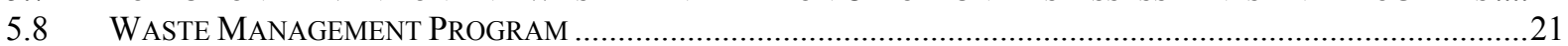

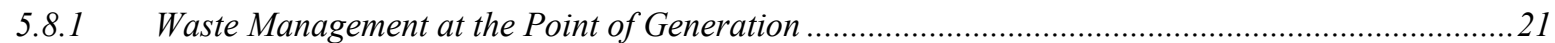

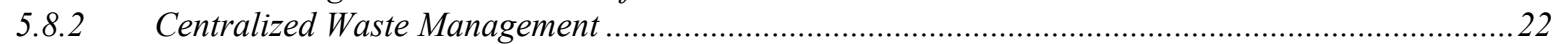

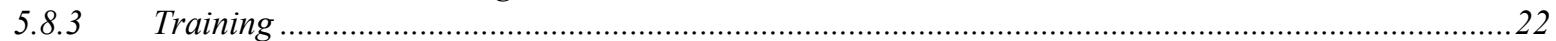

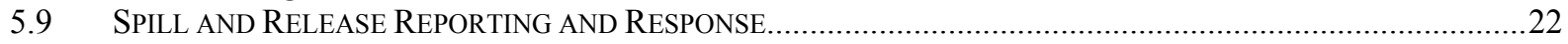

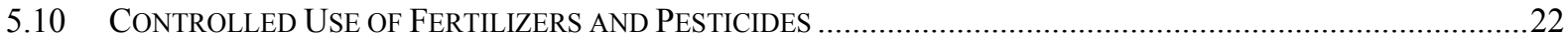

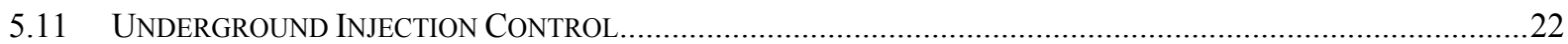

5.12 CONTROL OF TOXIC AND HAZARDOUS MATERIALS STORAGE FACILITIES ……........................................2

5.13 WeLLHEAd PROTECTION FOR POTABLE SUPPLY WELLS ..........................................................................23 


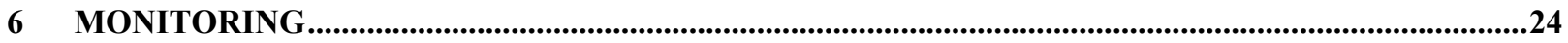

6.1 BNL GROUNDWATER MONITORING PROGRAMS - DESIGN AND IMPLEMENTATION …….............................24

6.2 GROUNDWATER AND DRINKING WATER MONITORING STANDARDS ….................................................25

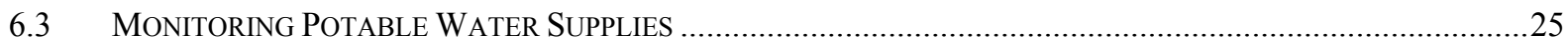

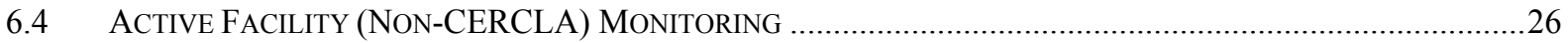

6.4.1 Monitoring of Potential Radiological Source Areas ………......................................................2

6.4.2 Monitoring of Potential Chemical Source Areas ………..............................................................2

6.5 ENVIRONMENTAL RESTORATION GROUNDWATER MONITORING PROGRAM (CERCLA) ……....................28

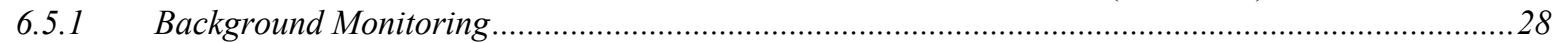

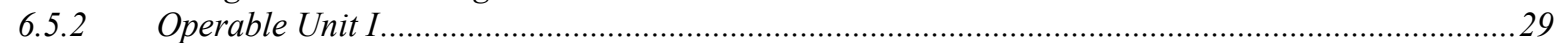

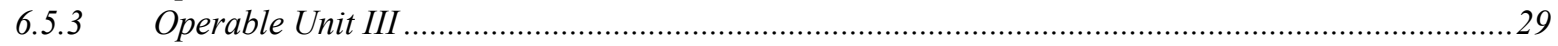

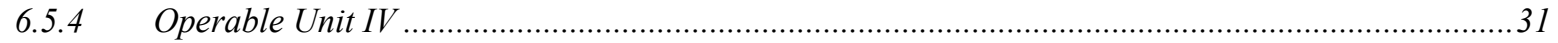

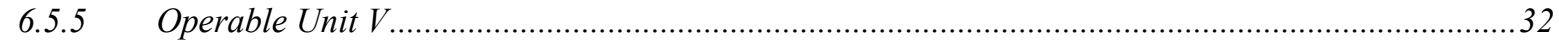

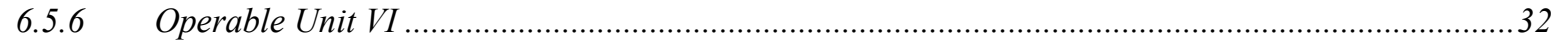

6.6 LIQUID EFFLUENT MONITORING PROGRAM ………............................................................................

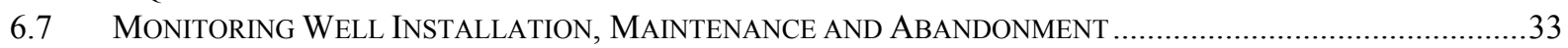

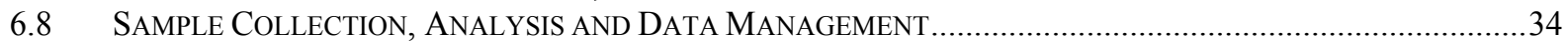

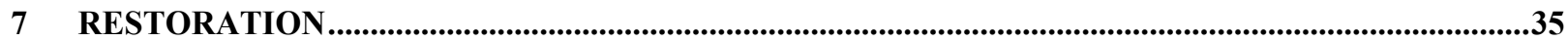

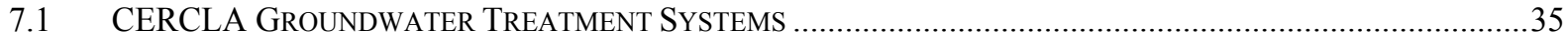

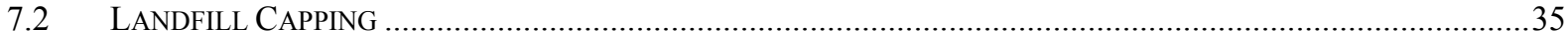

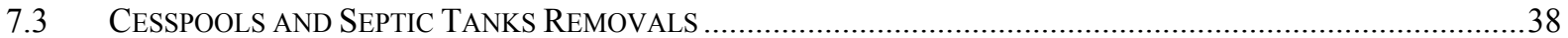

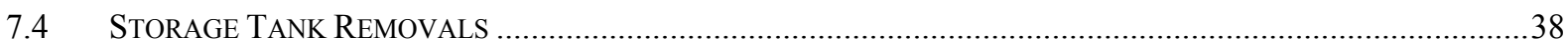

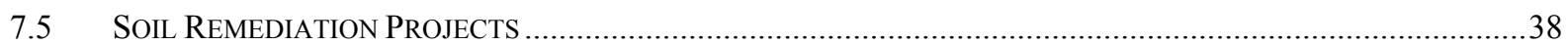

7.6 REACTOR FACILITY DECONTAMINATION AND DECOMMISSIONING PROJECTS ...........................................38

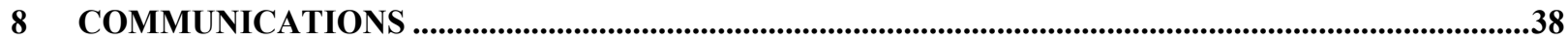

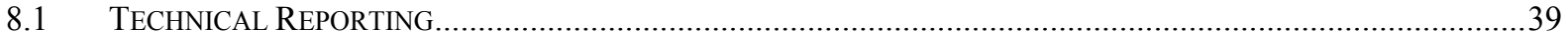

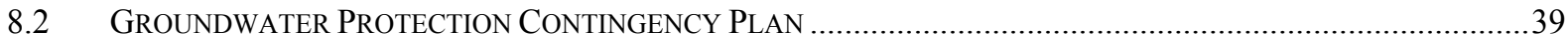

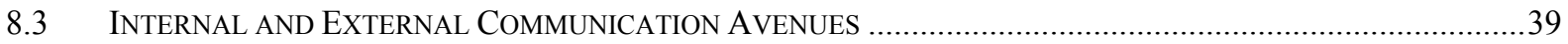

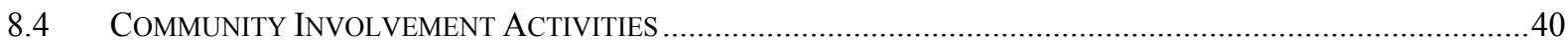

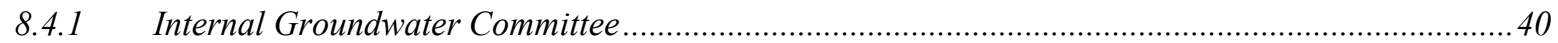

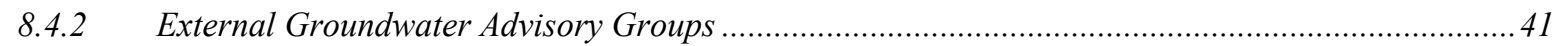

8.4.3 Communications with Regulatory Agencies..................................................................................... 41

9 PERFORMANCE METRICS AND SYSTEMS FOR CONTINUOUS IMPROVEMENTS .....................41

Appendix A References

Appendix B Environmental Regulations

Appendix C Environmental Stewardship Policy 


\title{
Brookhaven National Laboratory Groundwater Protection Management Program Description
}

\author{
List of Figures and Tables
}

Figure 1. BNL Groundwater Protection Management Program - Document Hierarchy.................

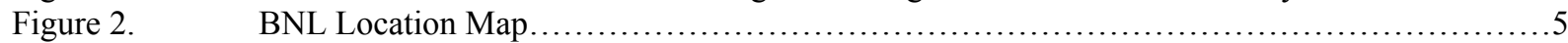

Figure 3. Generalized Geologic Cross Section in the Vicinity of BNL.............................. 6

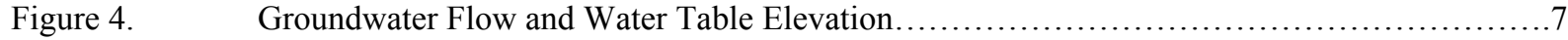

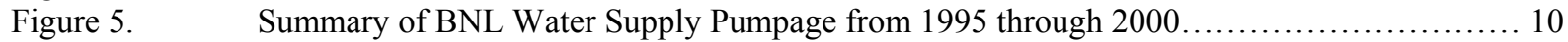

Figure 6. Locations of Suffolk County Water Authority Public Supply Wells in the Vicinity of BNL....12

Figure 7. Map of BNL CERCLA Areas of Concern/Operable Units................................14

Figure 8. Active Research and Support Facilities with Controls to Prevent Contamination

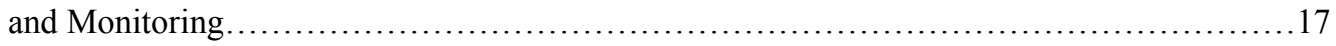

Figure 9. BNL Groundwater Protection Service Model Concept...................................19

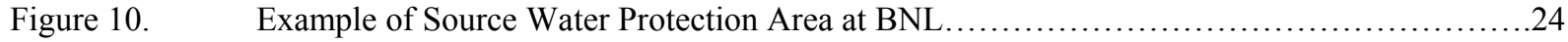

Figure 11. Location of Active and Planned Groundwater Remediation Systems.......................36

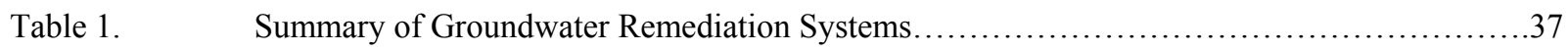




\section{List of Acronyms}

\begin{tabular}{|c|c|}
\hline AGS & Alternating Gradient Synchrotron \\
\hline $\mathrm{AOC}$ & Area of Concern \\
\hline ASL & BNL Analytical Services Laboratory \\
\hline BGRR & Brookhaven Graphite Research Reactor \\
\hline $\mathrm{BHO}$ & DOE Brookhaven Area Office \\
\hline BLIP & Brookhaven LINAC Isotope Producer \\
\hline BMRR & Brookhaven Medical Research Reactor \\
\hline $\mathrm{BNL}$ & Brookhaven National Laboratory \\
\hline BSA & Brookhaven Science Associates \\
\hline CERCLA & Comprehensive Environmental Response, Compensation and Liability Act \\
\hline $\mathrm{CT}$ & Carbon Tetrachloride \\
\hline CY & Calendar Year \\
\hline DCA & 1,1-dichloroethane \\
\hline DCG & Derived Concentration Guide \\
\hline $\mathrm{DOE}$ & U.S. Department of Energy \\
\hline ESD & Environmental Services Division \\
\hline EMS & Environmental Management System \\
\hline EM & Environmental Management Directorate \\
\hline EPA & U.S. Environmental Protection Agency \\
\hline ERD & Environmental Restoration Division \\
\hline FY & Fiscal Year \\
\hline GPMP & Groundwater Protection Management Program \\
\hline HFBR & High Flux Beam Reactor \\
\hline IAG & Interagency Agreement \\
\hline LINAC & Linear Accelerator \\
\hline MPF & Major Petroleum Facility \\
\hline MTBE & Methyl Tertiary Butyl Ether \\
\hline NPL & National Priorities List \\
\hline NYSAWQS & New York State Ambient Water Quality Standard \\
\hline NYSDEC & New York State Department of Environmental Conservation \\
\hline NYSDOH & New York State Department of Health \\
\hline NYSDWS & New York State Drinking Water Standard \\
\hline OU & Operable Unit \\
\hline PCE & Tetrachloroethylene \\
\hline $\mathrm{pCi} / \mathrm{L}$ & Pico Curies per Liter \\
\hline RCRA & Resource Conservation and Recovery Act \\
\hline RHIC & Relativistic Heavy Ion Collider \\
\hline $\mathrm{RI} / \mathrm{FS}$ & Remedial Investigation/Feasibility Study \\
\hline ROD & Record of Decision \\
\hline SDWA & Safe Drinking Water Act \\
\hline SCDHS & Suffolk County Department of Health Services \\
\hline SPDES & State Pollution Discharge Elimination System \\
\hline STP & Sewage Treatment Plant \\
\hline TCA & $1,1,1$-trichloroethane \\
\hline TCE & Trichloroethylene \\
\hline$\mu \mathrm{g} / 1$ & Micrograms per Liter \\
\hline UST & Underground Storage Tank \\
\hline VOC & Volatile Organic Compounds \\
\hline WCF & Waste Concentration Facility \\
\hline WMF & Waste Management Facility \\
\hline
\end{tabular}




\section{Brookhaven National Laboratory Groundwater Protection Management Program Description}

\section{PURPOSE AND CONTENT OF THIS DOCUMENT}

U.S. Department of Energy (DOE) Order 5400.1, "General Environmental Protection Program," requires all DOE facilities to establish a Groundwater Protection Management Program (GPMP). The purpose of Brookhaven National Laboratory's (BNL) GPMP is to ensure that plans for groundwater protection, management, monitoring, and restoration are fully defined, integrated, and managed in a cost-effective manner that is consistent with federal, state, and local regulations.

This document outlines activities related to protection of the sole source aquifer underlying BNL. The BNL GPMP includes policy, objectives, strategy, requirements and regulations applicable to groundwater protection, an overview of groundwater resources (quality, quantity and uses), programs to prevent groundwater pollution, potential sources of groundwater pollution, a summary of the groundwater monitoring program, and programs to communicate with stakeholders about the groundwater program.

The BNL GPMP description document is reviewed annually and updated at least every three years. ${ }^{1}$ This is done as part of the continual improvement aspect of BNL's Environmental Management System (EMS), and to ensure that the groundwater program is effective and reflects current operational practices at BNL. Figure 1 depicts how the GPMP relates to other BNL documents and programs.

\section{APPROACH}

\subsection{BNL Environmental Stewardship Policy}

BNL's environmental stewardship policy is found in Appendix C. With regard to groundwater, BNL is committed to protecting groundwater resources existing beneath and downgradient of BNL from further chemical and radionuclide releases, and remediating existing contaminated groundwater.

\subsection{Groundwater Protection Program Strategy}

The primary goal of the BNL Groundwater Protection Management Program is to ensure that plans for groundwater protection, management, monitoring, and restoration are fully defined, integrated, and managed in a cost-effective manner that is consistent with federal, state, and local regulations. The groundwater protection program consists of four interconnected elements:

1) Prevention of contaminants from ever entering the groundwater flow system;

2) Monitoring groundwater as well as other environmental media;

3) Restoration of existing degraded soil and groundwater; and,

4) Consistent and timely internal and external communication.

1 This document replaces the document entitled Brookhaven National Laboratory Groundwater Protection Program Description, dated December 23, 1998 (Paquette et al., 1998). 


\section{BNL GROUNDWATER RELATED DOCUMENT HIERARCHY}

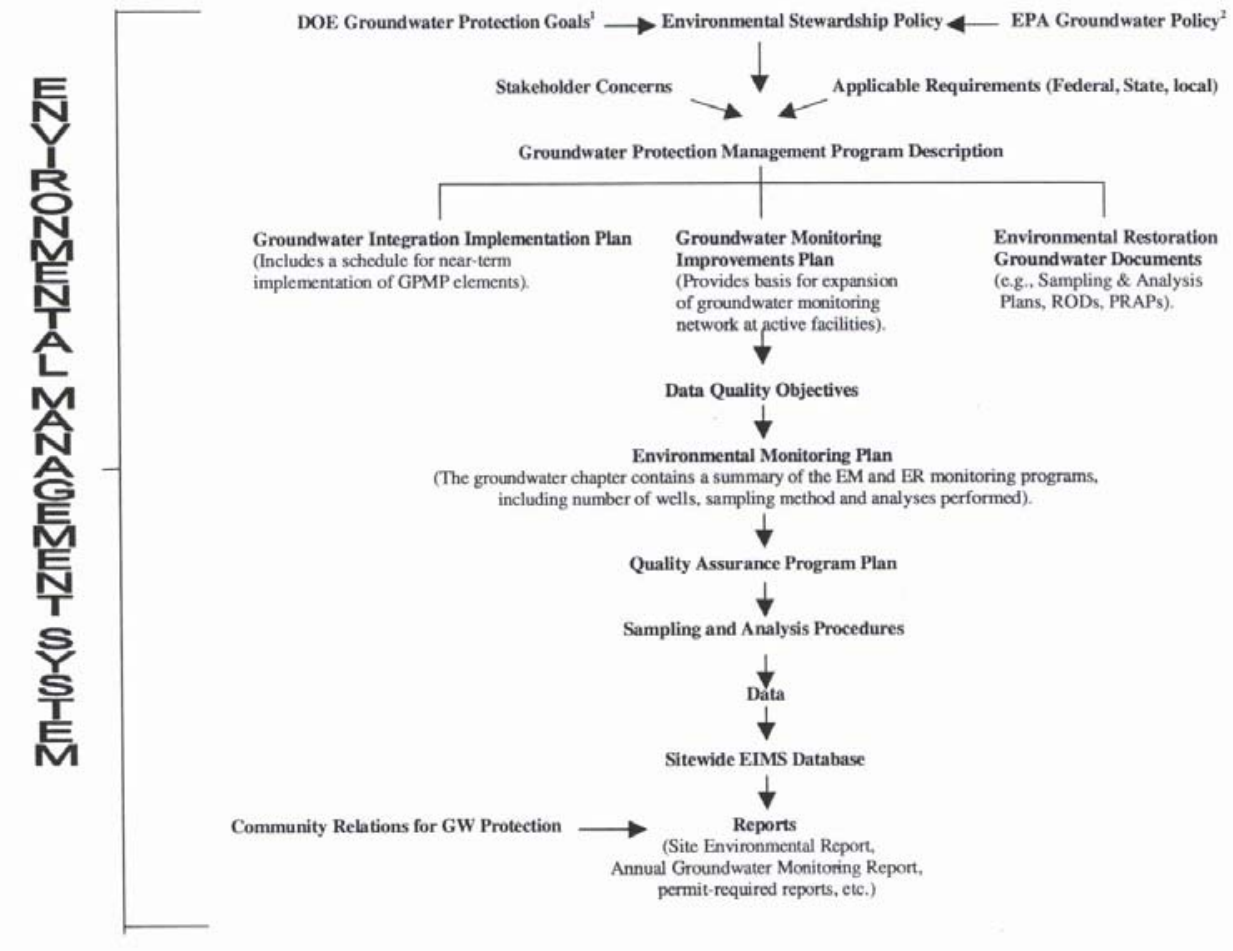

'Groundwater Protection Goals in DOE Order 5400.

${ }^{2} \mathrm{EPA}(1991$

Figure 1. BNL Groundwater Protection Management Program Document Hierarchy

Prevention: To protect groundwater resources from further contamination, BNL has implemented a three-phased project to: 1) identify past or current activities with the potential to impact environmental quality; 2) conduct a BNL-wide review of all experiments and industrial-type operations to determine the potential impacts of those activities on the environment and integrate pollution prevention/waste minimization, resource conservation, and compliance into planning, decisionmaking and implementation; and 3) develop and implement an Environmental Management System. The prevention element is described in more detail in Section 5.0 of this document.

Monitoring: Groundwater monitoring is being conducted under two programs - the Environmental Surveillance (ES) Program and the Environmental Restoration (ER) Program. The ES Program is designed to satisfy DOE monitoring requirements for active research and support facilities, and to satisfy the monitoring requirements of New York State operating permits for the Major Petroleum Facility and the new Waste Management Facility. The Environmental Restoration Program conducts groundwater monitoring related to BNL's obligations under CERCLA (e.g., remedial investigation, landfill closure, and remediation system monitoring). Data Quality Objectives, well installation procedures, sampling and analysis, data management, and well maintenance and abandonment programs will be properly integrated to optimize the groundwater monitoring system. The monitoring element is described in more detail in Section 6.0 of this document. 
Restoration: BNL was added to the National Priorities List in 1989. Thirty Areas of Concern have been grouped into six Operable Units. Remedial Investigation/Feasibility Studies have been conducted for each Operable Unit. A primary goal of the Environmental Restoration program is remediating soil and groundwater contamination, and preventing additional groundwater contamination from migrating off-site. To that end, contaminant sources (e.g., contaminated soil, underground tanks, etc.) are being removed or remediated to prevent further contamination of groundwater. The performance objectives for groundwater restoration are: 1) minimize contaminant plume growth; 2) meet drinking water standards in groundwater for all volatile organic compounds, strontium-90 and tritium; and 3) complete cleanup of the groundwater in Upper Glacial aquifer in thirty years or less. The restoration element is described in more detail in Section 7.0 of this document.

Communication: BNL has a community involvement, government and public affairs program to ensure that BNL communicates with the community in a consistent, timely and accurate manner. The majority of communications regarding groundwater protection have been associated with the Environmental Restoration program. A number of communication mechanisms are in place, such as web pages, mailings, briefings and roundtables. Technical reports summarizing data, evaluations, and program indices are prepared annually. A Groundwater Protection Contingency Plan has also been developed as a lab-wide procedure to guide technical action and communication with Laboratory management and stakeholders in the event of off-normal groundwater data. The communication element is described in more detail in Section 8.0 of this document.

\subsection{Applicable Requirements}

The requirements for the protection, preservation and restoration of groundwater resources are addressed in a number of Federal, New York State, and local laws and regulations. Performance standards for groundwater monitoring at these facilities are specified in regulations promulgated under the Resource Conservation and Recovery Act (RCRA), the Comprehensive Environmental Response, Compensation and Liability Act (CERCLA), the Safe Drinking Water Act (SDWA), Clean Water Act (CWA), DOE Orders, State and local regulations. An overview of these groundwater protection requirements is presented in Appendices B.1 through B.4. BNL's goal is to comply with applicable requirements, and the following strategies are designed to ensure that this occurs.

\section{SITE INFORMATION}

\subsection{BNL Mission}

Brookhaven National Laboratory is a Department of Energy research facility. ${ }^{2}$ BNL's mission is to conceive, design, construct, and operate facilities to conduct complex fundamental scientific studies. The Laboratory is committed to produce excellent science in a safe, environmentally benign manner with the cooperation, support and appropriate involvement of its many stakeholders.

The Laboratory carries out basic and applied research in the physical, biological, and environmental sciences and in selected energy technologies. Programs include:

- High energy physics, presently centered on the operation of the Alternating Gradient Synchrotron (AGS) and the Relativistic Heavy Ion Collider (RHIC);

- Nuclear physics, with emphasis on heavy ions, kaons, and low energy physics;

- Life sciences and nuclear medicine, focused on fundamental life processes and their alteration by radiation and chemical pollutants, and on medical applications of nuclear techniques;

- Materials science, centered on utilization of the National Synchrotron Light Source;

2 BNL is managed for DOE by Brookhaven Science Associates, LLC, under DOE Contract No. DE-AC0298CH10886. The contract is administered by the DOE Chicago Operations Office (DOE-CH), through the DOE Brookhaven Group (DOE-BHG). 
- Chemical sciences, with emphasis on fundamental research into chemical and physical phenomena underlying energy-related transfer, conversion, and storage systems; and,

- Transferring to industry the knowledge and accomplishments of BNL research activities in order to support the nation's goal of achieving leadership in basic and applied sciences. BNL also maintains close interaction with scientific personnel from universities and industry, and aids in the education of scientists and engineers through cooperative research programs.

At BNL, there are over 350 experimental and support facilities, waste storage facilities, and former waste disposal facilities where hazardous or non-hazardous materials are currently or have previously been managed, including above and below ground storage tanks, landfills, liquid and solid waste management areas, scrap and storage yards.

\subsection{Site Description}

BNL is situated on 21.3 square kilometers (2,130 hectares), and is located close to the geographic center of Suffolk County on Long Island, New York, approximately $97 \mathrm{~km}$ (60 miles) east of New York City (Figure 2). An estimated 1.3 million persons reside in Suffolk County, 430,000 of whom live in Brookhaven Township, where BNL is located (LILCO, 1997). Approximately 8,000 persons reside within a half-kilometer of the BNL boundary. Although much of the land area within a $16 \mathrm{~km}$ radius of BNL remains either forested or cultivated, there has been an increase in residential housing development in areas surrounding the site. Although there have been no major construction projects in the vicinity since 1978, detailed plans for two shopping centers, a corporate park, and several thousand single and multiple family dwellings have recently been approved for areas within $15 \mathrm{~km}$ of BNL, predominantly to the north, west, and south of the site.

\subsection{Site Hydrogeology and Water Resources}

The U.S. Geological Survey initially studied the hydrogeology of the BNL site in the late 1940's and early 1950's under a cooperative agreement with the Atomic Energy Commission. Since these initial studies, groundwater flow patterns and groundwater quality have been impacted by a significant increase in the number of BNL research facilities and subsequent demands for water. Since the early 1990's, BNL has been conducting extensive subsurface investigations to better define the hydrogeological setting of the BNL site and surrounding areas. The BNL hydrogeologic characterization programs have included soil borings, geophysical logging, the installation of monitoring wells and piezometers, water level measurements, aquifer pumping tests, and groundwater modeling.

\subsubsection{Hydrogeology}

The BNL site is underlain by approximately $400 \mathrm{~m}(1,300 \mathrm{ft})$ of unconsolidated Pleistocene and Cretaceous sediments overlying Precambrian bedrock. The unconsolidated sediments, subdivided from youngest to oldest, are:

- Upper Pleistocene deposits (Upper Glacial aquifer),

- Gardiners Clay (Gardiners Clay confining unit),

- Magothy Formation (Magothy aquifer), and

- Raritan Formation (Raritan Clay confining unit and Lloyd aquifer). 


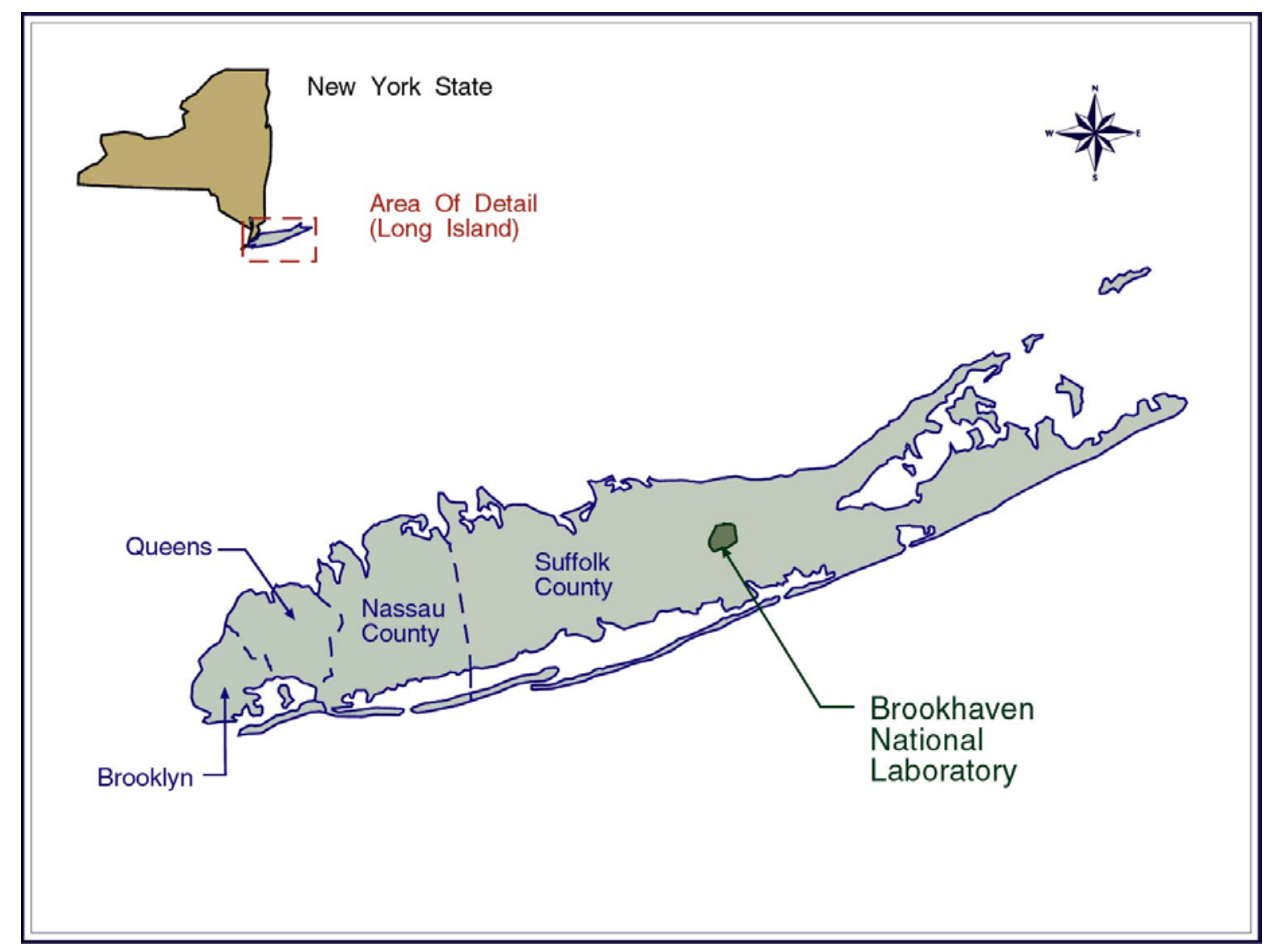

Figure 2. BNL Location Map

A brief description of the Upper Pleistocene, Gardiners Clay, and Magothy formation is provided below, and a generalized hydrogeologic cross section through Long Island and the BNL site is presented in Figure 3. Detailed discussions on the geology and hydrology of the BNL site can be found in deLaguna (1963), Faust (1963), Warren et al. (1968) and Scorca et al. (1999).

\subsubsection{Upper Pleistocene Deposits/Upper Glacial Aquifer}

Geology: The Upper Pleistocene deposits at BNL primarily consist of $40 \mathrm{~m}$ to $60 \mathrm{~m}$ ( $130 \mathrm{ft}$ to $200 \mathrm{ft}$ ) of broadly stratified glacio-fluvial outwash deposits composed of silica-rich medium to coarse-grained sand and gravel. Thin layers of silt and clay have been observed within the outwash deposits, but do not represent significant barriers to groundwater flow. Near surface silt and clay deposits are located along the lowlands of the Peconic River watershed. Although the full areal extent of these deposits has not been determined, their presence is inferred beneath marshes and areas of ponded water, which are wide-spread in the eastern portion of the site (see Warren et al., 1968, and Scorca et al., 1999). 


\section{Generalized Geologic Cross Section in Vicinity of \\ Brookhaven National Laboratory}

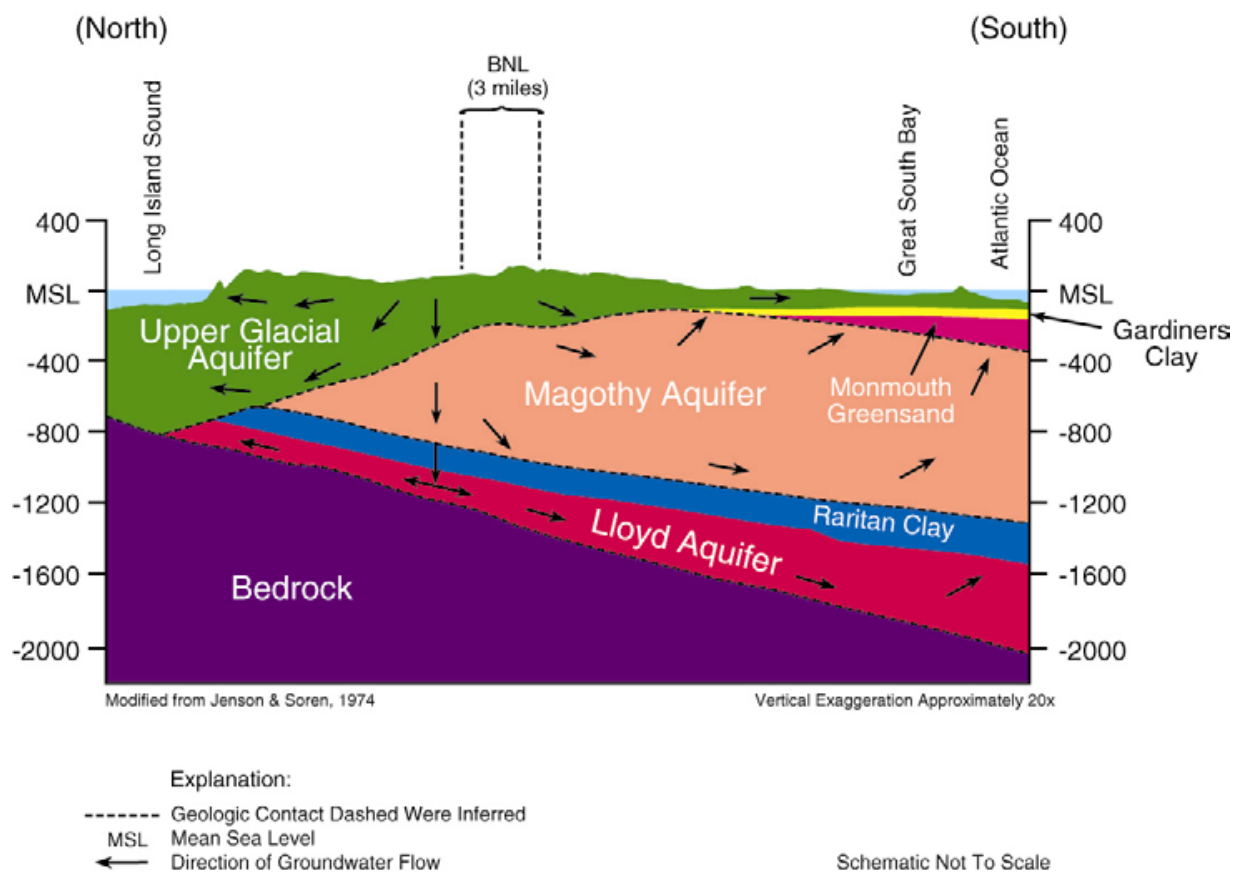

Figure 3. Generalized Hydrogeologic Cross-Section in the Vicinity of Brookhaven National Laboratory

Hydrology: Groundwater in the Upper Glacial aquifer beneath BNL generally exists under unconfined conditions. However, in the areas along the Peconic River where low permeability near surface silt and clay deposits exist, semiconfined conditions may occur. Depth to groundwater varies from several feet below land surface within the lowlands near the Peconic River, to as much as $23 \mathrm{~m} \mathrm{(75} \mathrm{ft)} \mathrm{in} \mathrm{the} \mathrm{higher} \mathrm{elevation} \mathrm{areas} \mathrm{located} \mathrm{in} \mathrm{the} \mathrm{central} \mathrm{and} \mathrm{western}$ portions of the site. The groundwater table is in the Upper Glacial aquifer. Shallow groundwater flow directions in the BNL area are influenced by natural drainage systems, varying between being eastward along the Peconic River, southeastward toward the Forge River, and southward toward the Carmans River (Figure 4). Additionally, supply well pumping and recharge induced stresses on the aquifer system are considerable in the central area of the site. Groundwater flow directions in the southwest corner of the site are also influenced by municipal water supply pumpage.

In most areas of the site, the natural groundwater flow velocity within the Upper Glacial aquifer is estimated to be approximately 0.23 meters per day $(\mathrm{m} / \mathrm{d})(0.75 \mathrm{ft} / \mathrm{d})$ (see Geraghty and Miller, 1996). However, flow velocities in recharge areas may be as high as $0.35 \mathrm{~m} / \mathrm{d}(1.45 \mathrm{ft} / \mathrm{d})$, while velocities up to $8 \mathrm{~m} / \mathrm{d}(28 \mathrm{ft} / \mathrm{d})$ have been calculated for areas near BNL potable and process supply wells (Woodward-Clyde Consultants, 1993). The BNL site is located within a Suffolk County Department of Health Services (SCDHS) designated deep-flow recharge area for the Magothy and Lloyd aquifers (Koppleman, 1978; SCDHS, 1987). Comparison of water level measurements from Upper Glacial aquifer and Magothy aquifer wells indicate significant downward flow across the BNL site. 


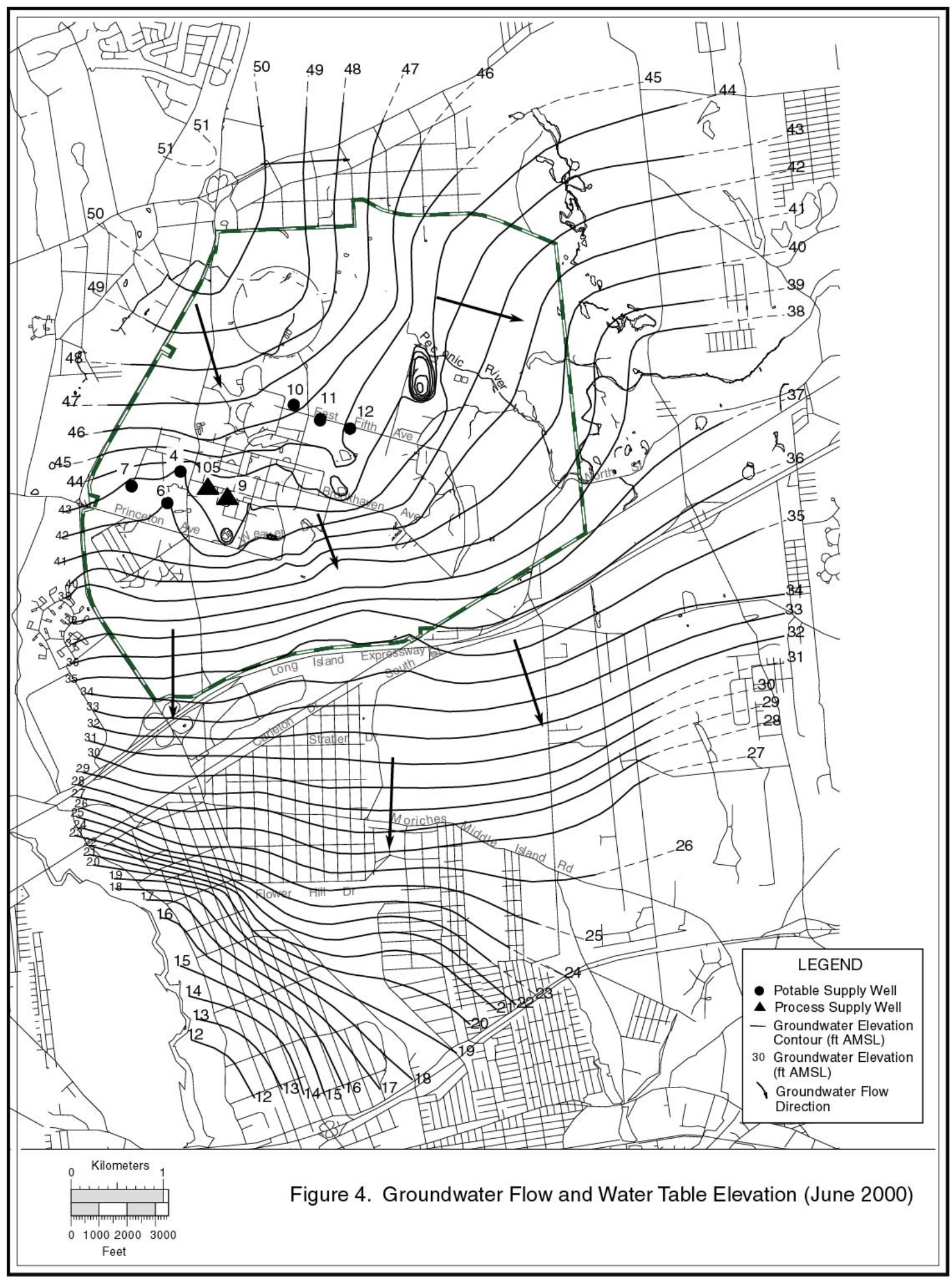




\subsubsection{Gardiners Clay Aquitard}

Geology: The Gardiners Clay is Pleistocene (Sangamon) in age, and unconformably overlies the Magothy formation. The Gardiners Clay deposits at BNL are composed of green-gray, silty and sandy clay ranging from $0.3 \mathrm{~m}$ to $4 \mathrm{~m}(2 \mathrm{ft}$ to $15 \mathrm{ft}$ ) in thickness. Thin sand and gravel zones have been observed within the Gardiners, which may reduce the effectiveness of this unit as a barrier to vertical groundwater flow. Where present, the Gardiners acts as a confining to semi-confining unit between Upper Glacial and Magothy aquifers.

On a regional scale, the Gardiners Clay has a wedge-shaped geometry that thickens to the south to a maximum of $46 \mathrm{~m}$ $(150 \mathrm{ft})$ in the Great South Bay area (deLaguna, 1963). The northern limit of the Gardiners Clay as a continuous unit is thought to be approximately $3.2 \mathrm{~km}$ (2 miles) south of BNL (Doriski and Wilde-Katz, 1983; Soren and Simmons, 1987; Smolensky et al., 1989).

Hydrology: To date, very little information exists on the hydraulic characteristics of the Gardiners Clay deposits at BNL. Limited studies by Warren et al. (1968) indicate that the permeability of the Gardiners Clay is approximately 0.3 $\mathrm{gpd} / \mathrm{ft}^{2}$. Sandy and silty zones that have been observed within the Gardiners Clay may reduce the unit's ability to restrict vertical groundwater movement. However, a hydraulic head differential across the Gardiners Clay has been observed in the southeast corner of BNL, between a shallow Upper Glacial well and a nearby upper Magothy well, indicating that the clay is sufficiently impermeable to restrict the downward movement of groundwater in this area. Due to the lack of continuous Gardiners Clay deposits, however, the Upper Glacial and Magothy aquifers may be hydraulically connected in a number of areas across the BNL site. In some areas of the site where the Gardiners Clay is absent, glacial sediments have been found to lie directly upon sandy zones or clay units within the uppermost Magothy.

\subsubsection{Magothy Formation/Magothy Aquifer}

Geology: The Magothy formation is characterized by Cretaceous aged terrestrial to transitional marine (deltaic) interbedded gray sand, gravel, silt, and clay. In the BNL area, the Magothy ranges from $244 \mathrm{~m}$ to $271 \mathrm{~m}(800-890 \mathrm{ft})$ in thickness (deLaguna, 1963). The basal $30 \mathrm{~m}$ to $46 \mathrm{~m}$ (100-150 ft) of the Magothy is composed primarily of coarse sand and gravel. Numerous discontinuous clay deposits are found within the uppermost Magothy underlying the BNL site. An erosional unconformity exists between the Magothy formation and the overlying Pleistocene deposits (Gardiners Clay or glacial deposits). Within the BNL area, the upper surface of the Magothy Formation ranges from $24 \mathrm{~m}$ to $49 \mathrm{~m}$ (80$160 \mathrm{ft}$ ) below mean sea level. Two significant erosional valleys have been identified at BNL. With a relief of $21 \mathrm{~m}(70$ $\mathrm{ft}$ ) or more, the erosional valleys reflect severe post-Gardiners erosion, which could have resulted from a combination of glacial scouring and the release of large amounts of glacial melt water. The erosional valleys were later filled with glacial sands and gravel, and reworked Magothy and Gardiners Clay sediments. The glacial sediments that fill these valleys rest directly upon Magothy sands or discontinuous clay layers within the upper Magothy.

Hydrology: The Magothy aquifer is the thickest hydrogeologic unit on Long Island. Where the Gardiners Clay overlies it, groundwater in the Magothy aquifer exists under confined conditions. Where the Gardiners Clay is absent, sand-rich zones within the uppermost portions of the Magothy may be hydraulically connected with the Upper Glacial aquifer. In these areas, the uppermost sections of the Magothy are under unconfined conditions. However, due to the presence of numerous discontinuous clay layers within the upper Magothy, the degree of confinement is likely to increase with depth. Although the upper Magothy clay units appear to be discontinuous, these clay units are likely to form significant local barriers to groundwater movement.

Data on the hydraulic characteristics of the Magothy aquifer below the BNL site are limited. Busciolano et al. (1998) have shown that groundwater flow directions within the Magothy are similar to the Upper Glacial aquifer, but less affected by surface drainage patterns. It is estimated that groundwater flow velocities within the Magothy may range between 0.009 to $0.43 \mathrm{~m} / \mathrm{d}(0.03$ to $0.14 \mathrm{ft} / \mathrm{d})$ (Warren et al., 1968). 


\subsubsection{Groundwater Classification and Use}

In Nassau and Suffolk Counties of Long Island, New York, drinking water supplies are obtained exclusively from groundwater aquifers (e.g., the Upper Glacial aquifer, the Magothy aquifer, and to a limited extent the Lloyd aquifer). The U.S. Environmental Protection Agency (USEPA) has designated these three water-bearing units in the as a Sole Source Aquifer System. ${ }^{3}$ Water in this system underneath the BNL site is classified as "Class GA Fresh Groundwater" by the State of New York. ${ }^{4}$

\subsubsection{BNL Water Supply}

The Magothy aquifer is the most widely used aquifer for public water supply (Soren and Simmons, 1987). In the BNL area, only Suffolk County Water Authority (SCWA) supply wells actively withdraw water from the Magothy aquifer.

The Upper Glacial aquifer is also widely used on Long Island for both private and public water supply. Drinking water and process water supplies at BNL are obtained exclusively from on-site wells that draw water from the Upper Glacial aquifer. BNL currently operates and maintains six drinking (potable) water/process water supply wells (Wells 4, 6, 7, 10, 11, and 12), one well dedicated for process water supply (Well 9), and an extensive water distribution system. ${ }^{5}$ Former process supply well 102, which was used to supply secondary cooling water to the Alternating Gradient Synchrotron (AGS) facility, is currently maintained in an inactive state for use as an emergency source of drinking water. Locations of the BNL potable supply wells are shown in Figure 4.

During maximum water usage at BNL, up to 23 million liters per day (MLD) are pumped from the Upper Glacial aquifer. Most of this water is returned to the aquifer by way of recharge basins and discharge of Sewage Treatment Plant (STP) effluent to the Peconic River. The BNL water supply wells are screened within the Upper Glacial aquifer, and most wells are capable of delivering up to 4,500 liters per minute (lpm) $(1,200$ gallons per minute) to the potable water system. The supply wells are used in rotation to meet the daily water supply requirements for the site.

\subsubsection{Potable Water Treatment}

Potable water obtained from BNL Supply Wells 4, 6, and 7 contains naturally occurring iron at concentrations that exceed NYS Drinking Water Standards (NYSDWS). Before entering the distribution system, this water is first treated at the BNL Water Treatment Plant (WTP) using a conventional lime softening process to precipitate the iron from solution. Chlorination of the water supplied from Wells 4, 6, and 7 is accomplished by the use of sodium hypochlorite at the WTP, and individual sodium hypochorite dosing systems are installed at Wells 10,11, and 12. Water obtained from the Upper Glacial aquifer is naturally slightly acidic, with a $\mathrm{pH}$ in the range of 5.5 to $6.5 \mathrm{SU}$. To reduce the corrosivity of the water, sodium hydroxide is added to maintain the $\mathrm{pH}$ of the potable water at approximately $8 \mathrm{SU}$. By increasing the alkalinity of the water, the dissolution of lead from older soldered pipe joints is reduced. Occasionally, water pumped from some of the water supply wells may contain VOCs at concentrations slightly exceeding NYS DWS. Water obtained from Potable Supply Wells 10, 11, and 12 is treated at the wellhead using large capacity carbon filters, whereas water from Wells 4, 6, and 7 is treated at the Water Treatment Plant by the use of air stripping towers.

3 This designation of the "Nassau/Suffolk Aquifer System"was made on June 21, 1978, pursuant to Section 1424(e) of the Safe Drinking Water Act.

4

5

6NYCRR Parts 700-705.

The BNL supply wells are operated under NYSDEC Long Island Well Permit \#1-4722-00032/00113 granted to the DOE on September 14, 1998. BNL submits an annual Water Pumpage Report to the NYSDEC, which summarizes total pumpage for all BNL potable and process supply wells, and remediation wells. 


\subsubsection{Water Supply Management}

Managing groundwater consumption at BNL and understanding the effects of groundwater withdrawals on regional hydrogeologic regime are important components of the BNL GPMP. The Upper Glacial aquifer is highly permeable, and yields significant quantities of water throughout the BNL area. The present rate of groundwater pumpage at BNL, coupled with significant recharge after use (recharge of $>75 \%$ when combining sewer line losses and discharges to the Sewage Treatment Plant and recharge basins), results in only a minor net loss in the quantity of water stored in the Upper Glacial aquifer. However, because pumping of supply wells and subsequent recharge of this water causes significant changes in groundwater (and possibly contaminant) flow directions and velocities, conservation of water by minimizing pumping is important. Since the mid- 1990s, total pumpage from the water supply wells has been reduced from approximately 1.3 to 0.7 billion gallons per year (Figure 5). This reduction has been realized by the implementation of water conservation projects, which have included distribution system upgrades to prevent water loss and the identification of wasteful water use practices.

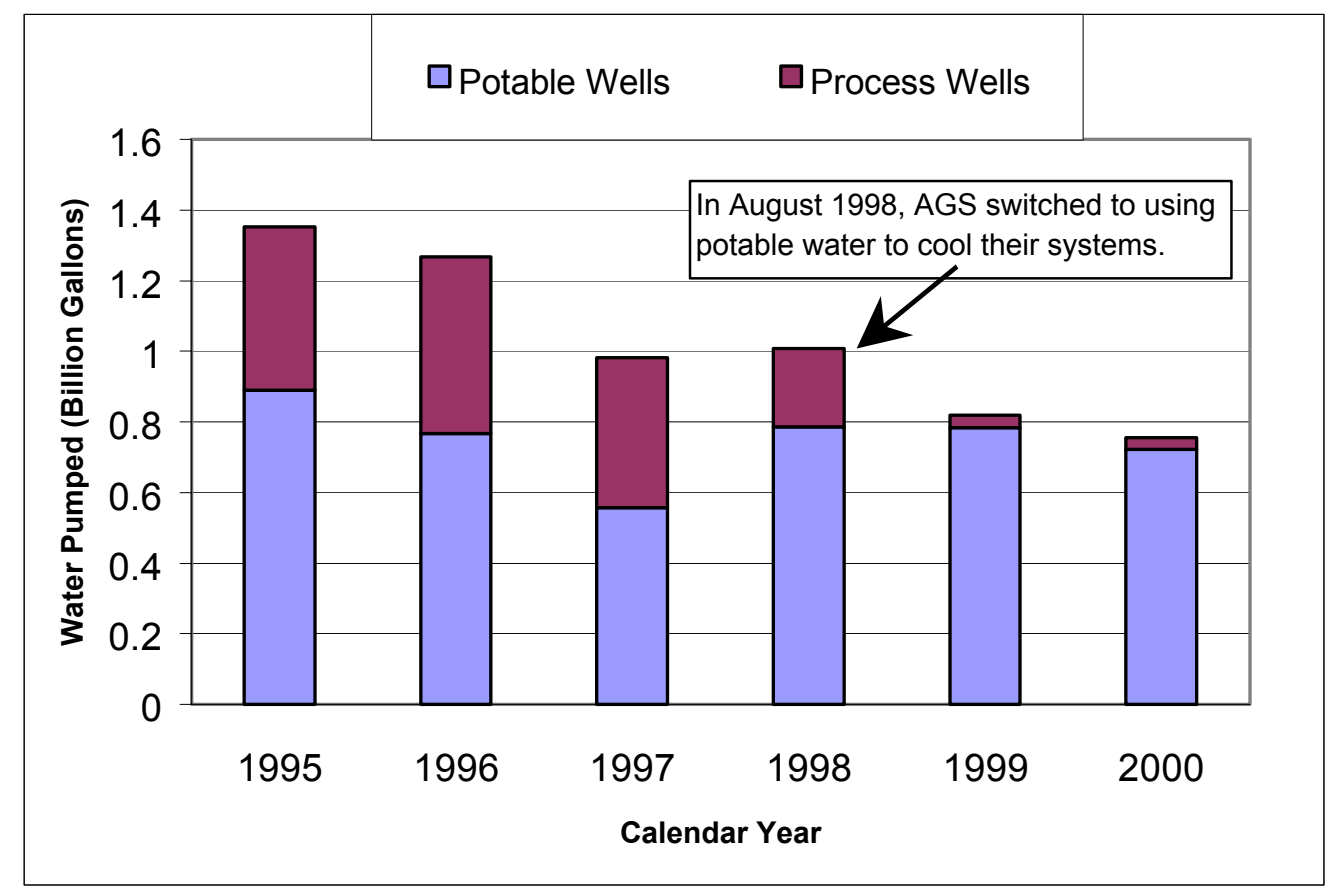

Figure 5. Summary of BNL Potable Water Supply Pumpage from 1995 through 2000

Assessment of future water supply requirements is outlined in the BNL Water Utility Master Plan, 1989-2000 (BNL, 1989). The Master Plan includes an assessment of needed water supply system upgrades (e.g., new distribution lines, treatment and storage facilities, and well modifications and replacements), daily water demands, fire fighting capabilities, and predicted growth. Based upon assessments of predicted growth in employee population and potential water demands for planned future research and support facilities, the current supply well network is capable of providing adequate supply of both potable and non-contact coolant water for the site. However, in order to maintain proper flow and pressure conditions, modifications to the existing distribution system may be required.

\subsubsection{Off-Site Public Water Supply}

The SCWA operates a number of public water supply well fields in the vicinity of BNL. The locations of the nearby SCWA supply wells are shown in Figure 6. The closest of these, the William Floyd Well Field, is located $0.2 \mathrm{~km}$ to the southwest of BNL. The William Floyd well field yields approximately 4.5 MLD from two Upper Glacial wells and one Magothy aquifer well. 
As part of the IAG activities, approximately 1,500 homes in the neighboring North Shirley, East Yaphank and Manorville areas have been connected to SCWA supply. This initiative was undertaken as a precautionary measure to eliminate any possible future exposure to groundwater contaminants originating from BNL. Homeowners who preferred not to be connected to SCWA supply continue to be serviced by individual, small capacity wells $(<80 \mathrm{lpm})$ that are typically screened in the uppermost $15 \mathrm{~m}(50 \mathrm{ft})$ of the Upper Glacial aquifer.

\subsubsection{Surface Water Quality and Classification}

BNL is located near the western boundary of the Manorville drainage basin, which forms the upper drainage area or headwaters of the Peconic River. The Peconic River drains in an easterly direction into Flanders Bay, and then into the Great Peconic Bay.

Surface waters at BNL are classified by the State of New York as "Class C Fresh Surface Water" (6NYCRR Part 700705). The best usage of Class $C$ surface water is fishing, and is suitable for fish survival and propagation, and primary and secondary contact recreation.

Surface water bodies at BNL include the Peconic River, its tributaries (including associated wetlands) and isolated kettle ponds. These surface water bodies are in hydraulic communication with the Upper Glacial aquifer. Water levels and flow rates in the tributaries are strongly influenced by the position of the water table. Under natural conditions, flow in the Peconic River, and its tributaries, is derived primarily from groundwater discharge and surface water runoff. These surface water bodies are essentially dry during periods of regional drought. During periods of drought, BNL Sewage Treatment Plant (STP) effluent discharge to the Peconic River comprises the majority of the flow in the river, and most of the river flow recharges before reaching the BNL site boundary.

\subsubsection{BNL Groundwater Model}

The heterogeneous nature and distribution of Pleistocene and Cetaceous age geologic materials in the vicinity of BNL exert significant control on the movement of groundwater and contaminant transport. In addition, the groundwater flow patterns and rates vary with time in response to natural recharge effects and BNL water supply pumping and water recharge operations. These factors result in a rather complex hydrogeologic setting for BNL. To assist in understanding this hydrogeologic environment and managing the groundwater resource in the area, BNL has developed a threedimensional computerized groundwater flow and solute transport model of the area. The Regional BNL Groundwater Flow Model was developed in 1996 (Geraghty \& Miller, 1996) and was significantly updated in 1999 (Arcadis Geraghty \& Miller, 1999). This model is continually being updated as new hydrogeologic information is obtained. The model uses a three-dimensional finite difference solution to the groundwater flow equation. The computer program MODFLOW is used to obtain the flow solution. In addition, MT3D and MODPATH are utilized to better understand the site's flow patterns and fate and transport of contamination. From the Regional model, numerous "sub-models" have been developed for smaller scale groundwater monitoring and remediation projects, and to assist in managing water supply and recharging operations.

The BNL models have been developed, documented and applied in accordance with American Society of Testing Materials (ASTM) Standard Guides for groundwater modeling. The BNL Regional model was developed with the guidance of a groundwater modeling work plan that specified objectives, modeling tools, and methods. The work plan was reviewed and approved by the regulatory agencies. Each model application has specific objectives, and is documented and reviewed by internal users and the regulatory agencies. 


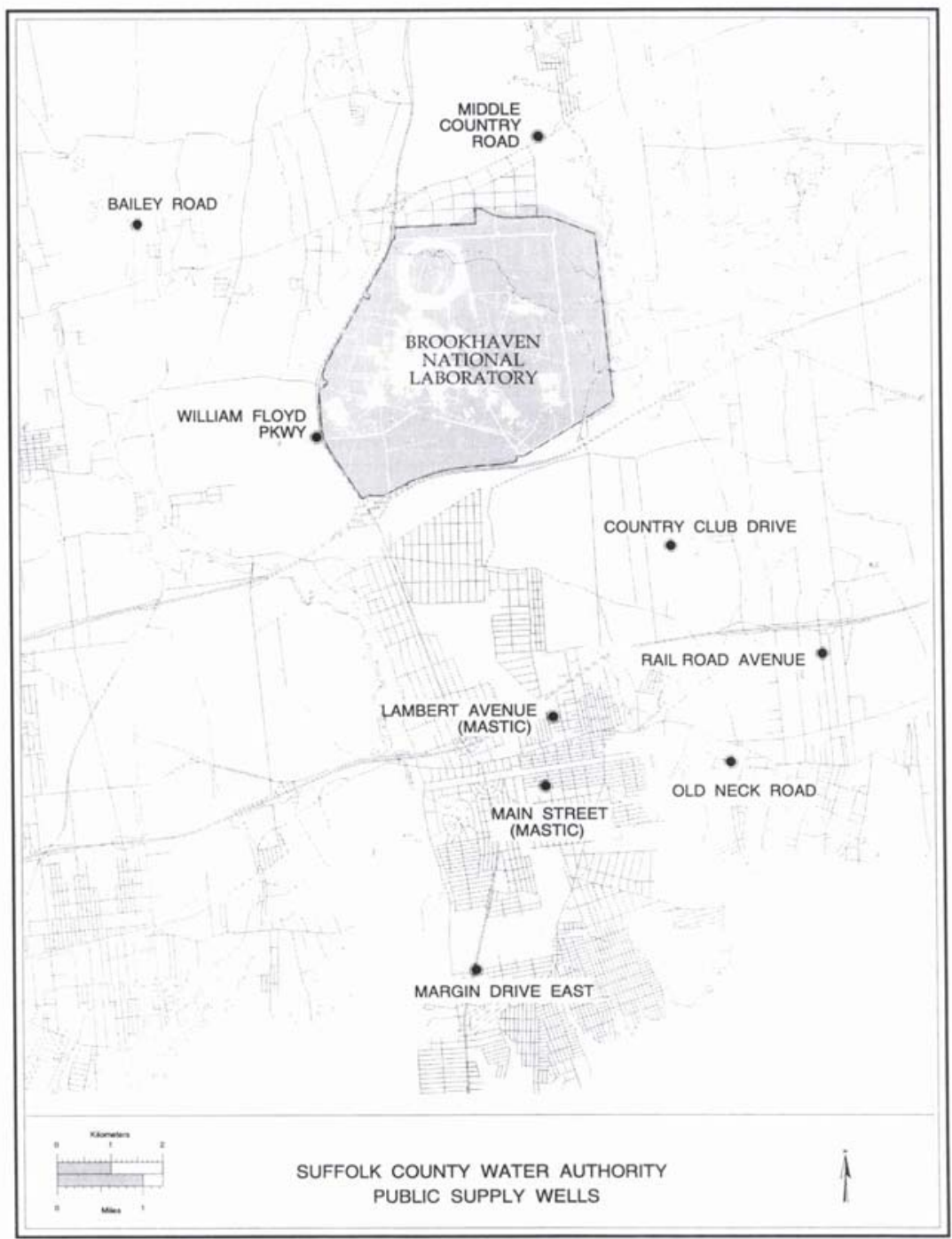

Figure 6. Locations of Suffolk County Water Authority Public Supply Wells in the Vicinity of BNL

Modeling in general is a simplified representation of the complex real world. Predicting contaminant fate and transport into the distant future is a challenging task. However, BNL is committed to an adaptive modeling philosophy where continuous learning from ongoing data collection and groundwater management activities are systematically applied to the models in such a way to make the best possible groundwater management and protection decisions. The suite of modeling tools is continuously evolving, and BNL stays current with model upgrades as they become available. BNL uses the most contemporary, most recognized, and most widely applied set of modeling tools (e.g., MODFLOW, MT3D, RT3D, and MODPATH).

\subsubsection{Groundwater Resource Vulnerability Assessment}

To guide groundwater protection efforts, an assessment has been made of the vulnerability of BNL's groundwater resources to pollution. To evaluate the vulnerability of the aquifer system to pollution, BNL utilized a USEPA 
methodology developed for evaluating groundwater pollution potential based upon hydrogeologic setting information (USEPA, 1985) and the BNL Source Water Assessment (Bennett et al., 2000). Some of the factors considered were:

- The Long Island aquifer system being classified as an EPA Designated Sole Source Aquifer,

- BNL's water supply is pumped from onsite wells screened in the shallow Upper Glacial aquifer,

- The Suffolk County Water Authority (the public water purveyor in the area) has a number of potable supply wells downgradient of the BNL site,

- The Peconic River, which is designated as a Wild and Scenic River and linked to the nationally significant Peconic Estuary, and other local surface water features are groundwater fed,

- The groundwater flow velocity is relative high in the shallow Upper Glacial aquifer, traveling at a rate of 0.6 to $1.2 \mathrm{ft} /$ day,

- The groundwater flow directions in the BNL area can be affected by water supply well pumping and water recharge operations, which could make it difficult to use monitoring wells for early warning of control failures,

- The depth to groundwater is relatively shallow ranging from 0 to 50 feet below ground surface,

- There is a relatively high rate of groundwater recharge in the area (approximately 22 inches per year of rainfall), which produces rapid migration of contamination through the vadose zone.

- There is a history of groundwater contamination at the site, and

- The hydrogeology of the area is reasonably well defined; the needs have shifted to groundwater management.

Based on these factors, the groundwater resource at BNL is vulnerable to pollution. Because of the value of groundwater at BNL and on Long Island, it warrants a significant effort to assure its protection. Without planning, protection and management, this renewable resource may not be available to support the BNL mission, its neighbors or future generations.

\section{KNOWN OR POTENTIAL SOURCES OF CONTAMINATION}

On December 21, 1989, the BNL site was identified as a federal Superfund site under the Comprehensive Environmental Response and Liability Act (CERCLA) program and placed on the National Priorities List (NPL). Thirty areas of concern (AOCs) have been identified through both ES and ER monitoring activities (see Figure 7). AOCs are areas where there have been releases to the environment of a hazardous substance, pollutant or contaminant. The characteristics of each AOC have been documented in the BNL Site Baseline Report (SAIC, 1992, and subsequent addendums). The 30 AOCs have been grouped into six Operable Units (OUs) based upon relative proximity of AOCs, similarity of contamination problems, similar geology and hydrology, and similar phases of remedial action to be performed. All of the OUs contain source areas that are known or suspected to have affected groundwater quality at the site. The AOCs/OUs are discussed in Section 4.1.

In addition to the defined AOCs that are being investigated and remediated as part of the Environmental Restoration Program, activities at a number of other active research and support facilities have resulted in low-level groundwater contamination or have the potential to impact groundwater. These facilities are discussed in Section 4.2.

\subsection{CERCLA Areas of Concern/Operable Units}

The AOCs were initially grouped into seven OUs (OUs I through VII) based upon relative proximity of AOCs, similarity of contamination problems, similar geology and hydrology, and similar phases of remedial action to be performed (see SAIC, 1992). Two of the OUs (II and VII) were later combined into a single project. Under the IAG, RI/FSs have been conducted for OUs I, III, IV, V and VI. The FS for OU II/VII (contaminated soils) was covered by the OU I FS. A brief description of each of the OUs follows. 


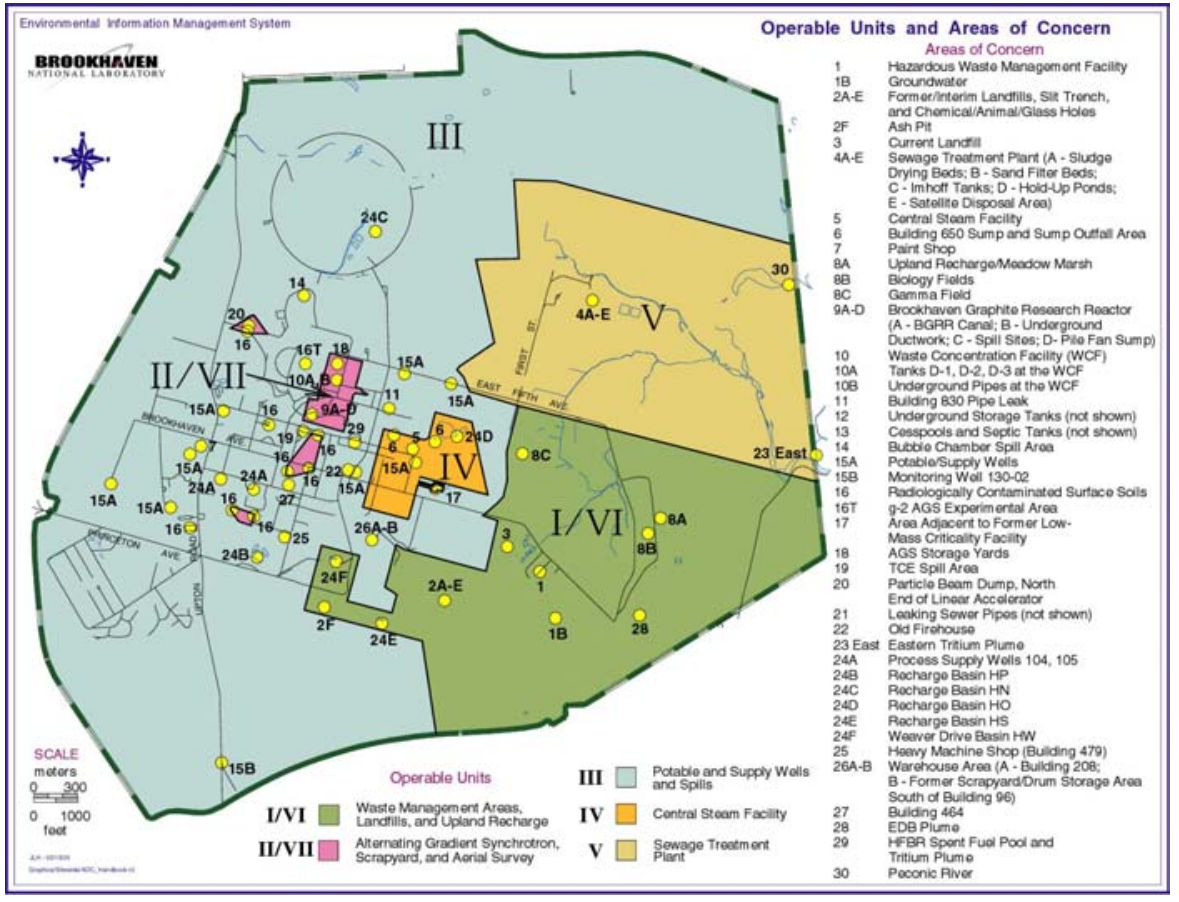

Figure 7. Map of BNL CERCLA Areas of Concern/Operable Units

- Operable Unit I: The OU I areas of concern deal with both chemical and radiologically contaminated soils and groundwater at the former Hazardous Waste Management Facility (HWMF), ${ }^{6}$ and the Former Landfill and Current Landfill areas. As a result of historical waste handling and disposal practices and accidental spills, soil and groundwater within the HWMF have been contaminated with VOCs and radionuclides. Groundwater investigations have detected VOCs such as 1,1,1-trichloroethane (TCA), trichloroethylene (TCE), tetrachloroethylene (PCE), 1,1dichloroethane (DCA), and 1,1-dichloroethylene (DCE). Radionuclides such as tritium and strontium-90 have also been detected in the groundwater. Residual contaminants of concern found in the soils at the facility are cesium-137 and strontium- 90 .

- Operable Unit II/VII: The OU II/VII areas of concern are primarily associated with radiologically contaminated soils. OU II/VII consists of four AOCs, including the Waste Concentration Facility (WCF), Aerial Radioactivity Monitoring System Results, an area adjacent to the former Low-Mass Criticality Facility, and the AGS Storage Yard. The nature and extent of contamination in these AOCs was evaluated during the OU II/VII RI/RA (ITC, 1998). A total of 23 areas of contaminated soils have been identified (AOC 16). Most of these areas contained lowlevel radiologically contaminated surface soils. The dominant isotopes found in these soils were cesium-137, sodium-22, manganese-54, cobalt-60, and thorium-230 (see CDM Federal, 1997; BNL, 1998a.

- Operable Unit III: The primary concern in this Operable Unit is contaminated groundwater originating from chemical and radiological releases that have occurred in the developed, central portion of the site. Twelve AOCs have been investigated as part of the OU III RI/FS (ITC/G\&M, 1998c). ${ }^{7}$ Some of the more significant defined

$6 \quad$ The HWMF was in operation from 1947 through December 1997.

$7 \quad$ Additionally, groundwater concerns associated with radiologically contaminated soils from Operable Unit II/VII were also transferred into the Operable Unit III RI/FS. 
source areas that have impacted groundwater include: 1) multiple solvent spill areas located within the AGS Complex $^{8}$ [AOC 14]; 2) TCA releases in the Supply and Materiel/Building 208 area (AOC 26); 3) the discharge of the solvents PCE, TCA, and CT in the former Building 96 area; 4) strontium-90 releases at the WCF; 5) strontium90 from the Former Landfill/Chemical Holes area; 6) strontium-90 releases from the BGRR; and 7) the tritium release from the HFBR spent fuel pool.

- Operable Unit IV: The primary areas of concern in OU IV are the 1977 Oil/Waste Solvent Spill (AOC 5) near the Central Steam Facility and the Building 650 Sump and Sump Outfall (AOC 6) (see CDM Federal, 1994, BNL, 1998b). In 1977, approximately 23,000 gallons of Number 6 fuel oil mixed with mineral spirits were released to soils from a ruptured transfer pipe. Soils and groundwater were impacted as a result of this spill. Residual VOCs and semivolatile organic compounds (SVOCs) had been detected in soils. Groundwater investigations detected high levels of toluene, xylenes, ethylbenzene, and PCE in wells near the spill site, with total VOC concentrations typically in the range of 4,000 $\mu \mathrm{g} / \mathrm{L} .{ }^{9}$ At Building 650 , drainage from historical outdoor decontamination of heavy equipment was routed to a drain system which emptied into a natural depression (known as the Building 650 Sump Outfall) located $240 \mathrm{~m}(800 \mathrm{ft}$.) to the northeast of the facility. Soils in the sump outfall are contaminated with cesium-137, europium-152, europium-154, strontium-90, radium-226, uranium-235/238, plutonium-239/240, americium-241, and cobalt- 60 .

- Operable Unit V: The areas of concern for OU V include: the Sewage Treatment Plant (STP) (AOC 4a through 4e); leaking sanitary lines (AOC 21); eastern tritium plume (AOC 23 East); and the Peconic River (AOC 30). The primary concern in this OU is the historical contaminant discharges to the BNL Sewage Treatment Plant (STP), which has been in continuous operation since 1947. Remedial investigation have identified contaminated soils near the STP filter beds, contaminated sediments within the Peconic River and an off-site TCE plume (ITC/G\&M, 1998a; ITC/G\&M, 1998b).

- Operable Unit VI: The primary concern in this OU is a plume of ethylene dibromide (EDB) contaminated groundwater that has migrated off-site (AOC 28). EDB was used as a pesticide to sterilize soils in the Biology Department's agricultural research fields in the 1960s and 1970s (CDM Federal, 1996c).

\subsection{Groundwater Quality near Active Research and Support Facilities (Non-CERCLA)}

Several active or planned facilities have inventories of hazardous or radioactive materials that could potentially create groundwater contamination problems if there were leaks in piping systems or tanks. Others have operations that create the potential for groundwater contamination by the direct activation of soils. ${ }^{10}$ Although groundwater quality at a number of these active facilities has already been impacted (e.g., the AGS area, Brookhaven LINAC Isotope Producer, Building 830, Motor Pool and Service Station), the levels of contamination in the remaining areas are either below or only slightly above applicable groundwater standards. See Figure 8 for a map of these facilities. A brief description of these facilities is provided below.

- Alternating Gradient Synchrotron Complex: Secondary particles created near AGS beam targets and stops have the potential to activate soils surrounding the accelerator tunnels or soils underlying target and beam dump areas in the experimental hall areas. Identified areas where soil activation can occur are: Building 912 (main experiment hall); AGS Booster Beam Scraper; E-20 Beam Catcher; Building 914 (transfer tunnel); g-2 Beam Target and Stop; J10 Beam Stop; and the former U-Line Target and Stop areas. The radionuclides of primary concern because of their

$8 \quad$ Cesspools/Septic Tanks and the Bubble Chamber spill site.

$9 \quad$ The OU IV Record of Decision was signed in March 1996.

10 Active research and support facilities that have the potential to impact groundwater quality are described in the BNL Groundwater Monitoring Improvements Plan for FY 1998 and FY 1999 (Paquette, 1998). 
potential to impact groundwater quality are tritium and sodium-22. Tritium has been detected at concentration exceeding the $20,000 \mathrm{pCi} / \mathrm{L}$ drinking water standard at three locations, the g-2 experiment, former E-20 Catcher, and the former U-Line Beam Stop. The highest contaminant levels are found in wells downgradient of a portion of the g-2 experiment beam line (VQ12 magnet area), with tritium and sodium- 22 concentrations of 1.8 million $\mathrm{pCi} / \mathrm{L}$ and $500 \mathrm{pCi} / \mathrm{L}$, respectively. To prevent rainwater from leaching these radionuclides from the soils and transporting them to the groundwater, impermeable caps have been constructed over these soil activation areas.

- Relativistic Heavy Ion Collider (RHIC) Facility: Secondary particles that will be created at the RHIC beam stop and collimator areas are expected to produce tritium and sodium-22 in soils immediately surrounding those areas. Impermeable caps have been placed over these soil activation areas to prevent rainwater infiltration.

- Brookhaven LINAC Isotope Producer (BLIP): Secondary particles created near the BLIP target vessel cause significant activation of soils within a four to five foot radius of the vessel. In 1998, tritium (up to 54,000 pCi/l) and sodium-22 (up to $151 \mathrm{pCi} / \mathrm{l}$ ) were detected in groundwater samples collected directly downgradient of BLIP.

- Brookhaven Medical Research Reactor (BMRR): The BMRR's primary cooling water system consists of a recirculation piping system that contains 2,550 gallons of water. The tritium concentration in the primary water is currently $465 \mu \mathrm{Ci} / \mathrm{L}$. Historical discharges of primary water to a floor drain system located in the basement of the BMRR have resulted in low-level tritium contamination of groundwater (concentrations typically less than 5,000 $\mathrm{pCi} / \mathrm{L})$.

- Sewage Treatment Plant Sand Filter Bed Area: Due to past chemical and radiological releases to the sanitary system, the filter bed sands have been contaminated with radionuclides and heavy metals. These radionuclides and heavy metals continue to leach from the sand filter beds at a slow rate (Schroeder et al., 1998). As much as $15 \%$ of the water released to the filter beds is subject to direct groundwater recharge. Combined with strict controls on discharges of chemicals or radioactive materials to the sanitary system, BNL has a monitoring program designed to detect unacceptable levels of contamination before the wastewater enters the STP facility.

- Sewage Treatment Plant (STP) Emergency Hold-up Ponds: If sanitary line monitoring detects unacceptable levels of contamination in sanitary wastewaters, this water can be diverted to lined holding ponds to allow for further analyses and possible treatment. In late 2001, the STP's two emergency holding ponds were re-lined and equipped with secondary containment and leak detection devices. Although the Laboratory performs routine maintenance on these ponds, the possibility exists that small-scale undetected leaks could occur in the liners.

- Major Petroleum Facility (MPF): The MPF is the holding area for fuel oil used at the Central Steam Facility. All fuel storage tanks are located in bermed containment areas, all fuel transfer piping is double walled and located above ground, and fuel inventory is carefully monitored. A potential undetected small-scale release of either free product or dissolved hydrocarbon products from the above ground storage tanks is of concern.

- Site Maintenance and Motor Pool Area: Environmental concerns at the Motor Pool include the use of underground storage tanks for the storage of gasoline and waste oil, hydraulic fluids used for lift stations, and the historical use of solvents for parts cleaning. Groundwater monitoring has detected low-levels of the solvent 1,1,1trichloroethane and the gasoline additive MTBE. These contaminants are related to historical operations. Current storage tanks and distribution lines are designed in accordance with regulatory requirements, and waste oils and solvent are properly stored and recycled. 


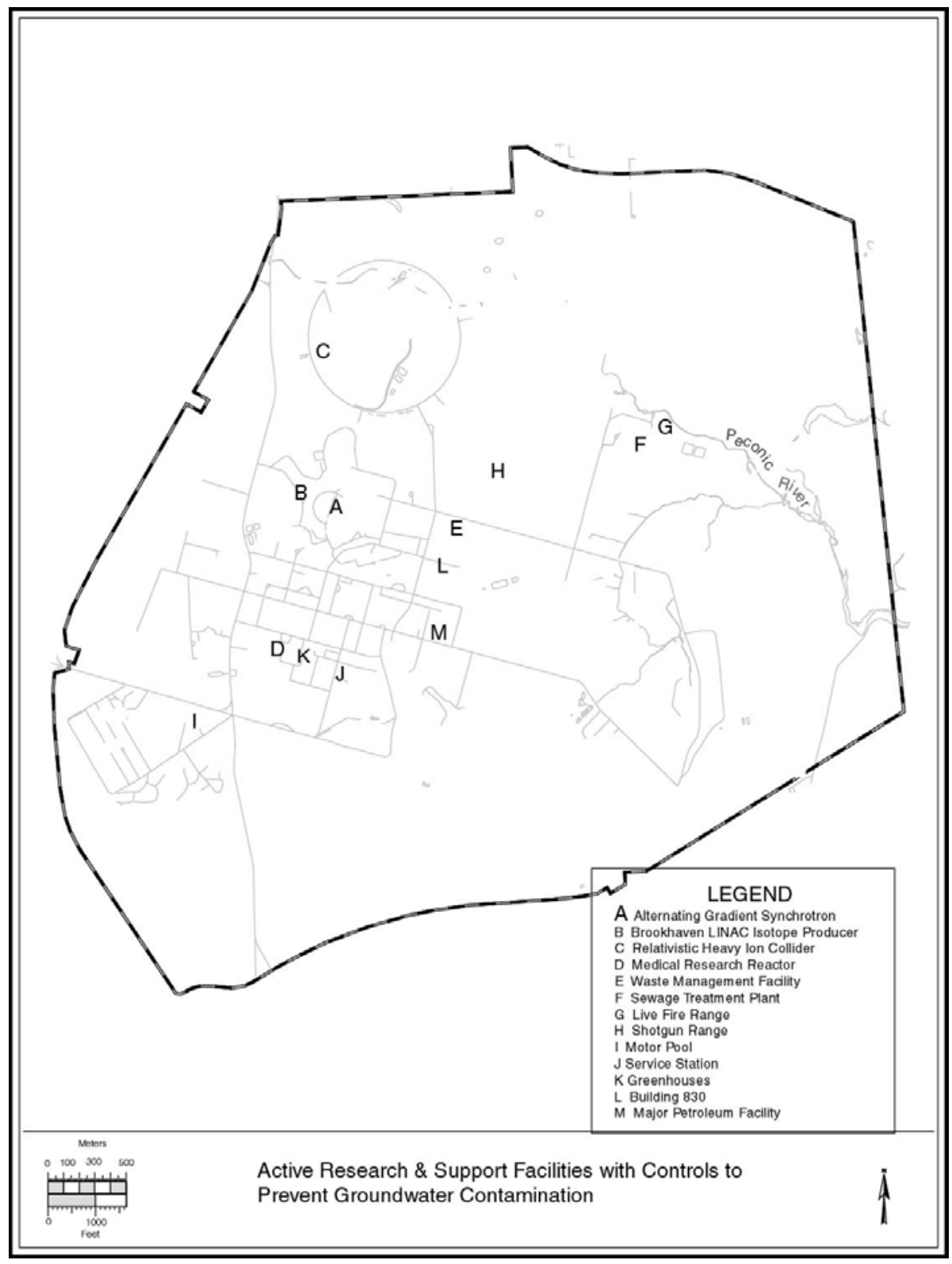

Figure 8. Active Research \& Support Facilities with Controls to Prevent Groundwater Contamination and Groundwater Monitoring

- On-site Gasoline Service Station: Environmental concerns at the Service Station include the historical use of underground storage tanks for the storage of gasoline and waste oil, hydraulic fluids used for lift stations, and the use of solvents for parts cleaning. Groundwater monitoring has detected petroleum hydrocarbons, the solvent tetrachloroethylene and the gasoline additive MTBE. These contaminants are related to historical operations. Current storage tanks and distribution lines are designed in accordance with regulatory requirements, and waste oils and solvent are properly stored and recycled. 
- Live-Fire (Rifle) and Shotgun Ranges: The use of on-site rifle and shotgun ranges may impact groundwater quality. Whereas most bullets are screened from the soils at the rifle range, lead shot at the shotgun range is not collected. Until the use of lead shot was discontinued in 2000 , it is estimated that several thousand pounds of lead shot was deposited on the surface of the shotgun range annually.

- Waste Management Facility: In December 1997, BNL began operating a new, state-of-the-art Waste Management Facility. Although the new WMF is designed and operated in a manner that meets all applicable Federal, State, and local environmental protection requirements, a groundwater monitoring program was established to provide a secondary means of verifying the effectiveness of the facility's engineering and operations controls.

\section{PREVENTION}

BNL has established a series of programs that are designed to prevent, to the greatest extent possible, the release of hazardous and radioactive material to the environment. The service model for integrating groundwater protection programs among BNL organizations is depicted in Figure 9. These program elements are described below.

\subsection{Environmental Management System}

An Environmental Management System (EMS) has been developed at BNL within the framework of a sitewide integrated Environment, Safety and Health Management System and based on the ISO 14000 Standard (Briggs, 1998). In 2001, BNL was ISO 14000 certified by NSF International Strategic Registrations, LTD. The goals of the EMS include ensuring that BNL conducts its work and manages the Laboratory facilities in a cost effective and efficient manner, while protecting workers, public and the environment. The EMS seeks to integrate environmental protection, pollution prevention, compliance assurance, remedial actions, and communication into all aspects of the Laboratory's mission. The GPMP applies the principles of the BNL EMS, and integrates them into its design and implementation. Key elements of the EMS that the GPMP supports include the following:

- Environmental Policy: The GPMP program is designed to support the lab-wide environmental stewardship policy, including the commitment to regulatory compliance, pollution prevention and continuous improvement;

- Objectives and Targets: The GPMP sets goals that establish the framework for the groundwater protection program;

- Legal and Other Requirements: The GPMP identifies the requirements applicable to the groundwater protection program, and incorporates these into Laboratory programs and procedures to ensure regulatory compliance;

- Environmental Management Program: The Groundwater Integration Implementation Plan (GIIP) contains plans for achieving the goals and objectives of the GPMP (BNL, 2000). The Lab-wide efforts (such as development of standards and procedures) needed to support the GPMP were developed as part of this plan;

- Communications: The GPMP has a communication element that is integrated with the BNL Strategic Communications Plan, utilizing the BNL Community, Education, Government and Public Affairs infrastructure for both internal and external communications;

- Monitoring and Measurement: One of the four elements of the GPMP is monitoring the Laboratory's impact on the environment; and,

- Records: Records for the sampling program are maintained in a centralized, integrated database.

In addition, a number of the programs described below are designed to anticipate and prevent environmental problems, and are being conducted or established within the EMS framework. 


\section{EXAMPLES OF \\ Groundwater Protection Integration}

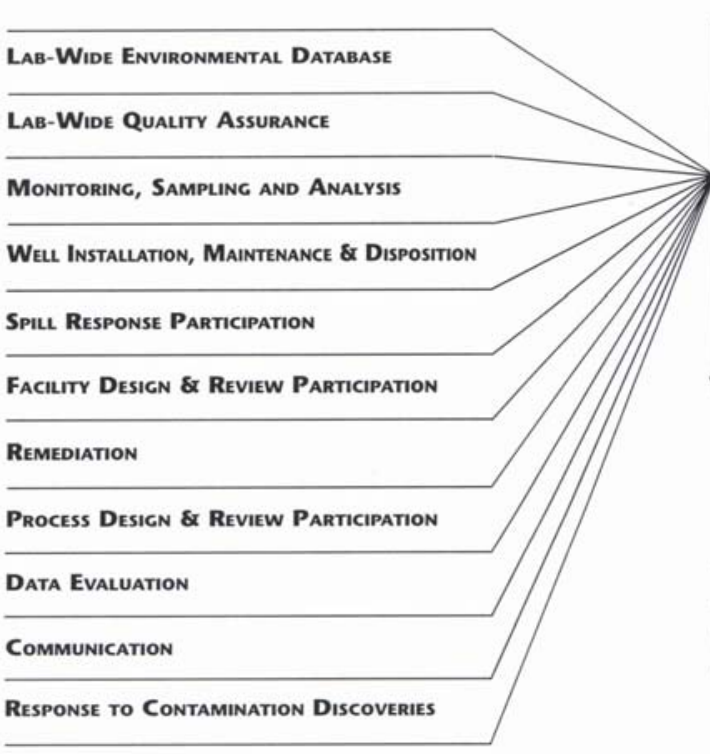

BNL Customers

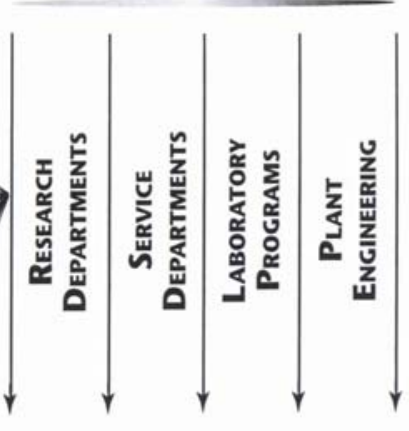

REsULts

- Efficient Planning

- Lab-Wide Coordinated Actions

- Quality On-Time Reporting

- Protected Groundwater

Resources

Figure 9. BNL Groundwater Protection Service Model Concept

\subsection{Environment, Safety and Health Standards}

BNL has established a series of procedures that describe requirements designed to prevent, to the greatest extent possible, the release of hazardous and radioactive material to the environment. These standards, which are found in BNL's Standards Based Management System, address the requirements of the National Environmental Policy Act (NEPA), radiological and non-radiological liquid effluents, air emissions, and hazardous, radioactive and mixed wastes.

\subsection{NEPA and Permit Compliance Review}

BNL's implementation of the NEPA process is detailed in the NEPA and Cultural Resource Evaluation Subject Area. The NEPA review and documentation process is initiated during the preliminary planning phases of a project. Permit applications and reviews are generally conducted during the detailed design phase, as the necessary project-specific design specifications become available.

\subsection{Facility Use Agreements}

Facility Use Agreements (FUA) establishing "landlord-tenant" requirements, roles and responsibilities have been instituted at BNL. The FUAs establish an "operating envelope" designed to comply with applicable regulatory requirements (including regulatory permits) and protect groundwater resources from specific activities occurring in that facility. Each agreement references environmental/groundwater protection criteria or programs that must be implemented. Furthermore, the FUAs describe each department's responsibilities to design, construct and maintain their 
facilities in a manner that protects groundwater resources. This includes administrative and/or engineered controls such as the development of standard operating procedures and/or operational procedures that require long-term inspection and maintenance of systems, and the construction or use of devices or structures designed to protect groundwater. The FUAs also identify monitoring requirements associated with each facility.

\subsection{Facility Design Reviews}

All proposed plans for major construction projects for new facilities or significant improvements to existing facilities are reviewed to ensure that the design elements meet all applicable regulatory requirements, and that potential environmental vulnerabilities are identified. The design review process is described in the Engineering Design Subject Area. All facilities that have the potential to store and handle radioactive and/or hazardous materials, or those that may directly activate soils (e.g., accelerator facilities such as the AGS and RHIC) must possess design features that are specifically intended to protect groundwater and surface water resources. At RHIC, for example, although the potential radionuclide concentrations in soil pore water are predicted to be well below drinking water standards, landfill-type geo-membrane caps have been constructed over the RHIC's collimator and beam stop areas as an added measure of groundwater protection. Assessment and design criteria for potential soil activation areas are described in the SBMS Accelerator Safety Subject Area.

- Internal Review: The design review process used by BNL is described in ES\&H Standard 1.3.0. The Plant Engineering program coordinates an internal review for each project. The review of project plans focuses on the soundness of design with respect environmental regulations (including measures taken to ensure groundwater protection), worker health and safety, and fire protection. For major facilities or operations that have the potential to produce conditions that could risk the health and safety of the public and employees, or that may impact environmental quality, a Safety Analysis Report, Safety Analysis Document, or an Environmental Impact Statement may be required.

- External Design Review: Following the completion of detailed drawings and specifications (Title II or $90 \%$ design stage), there may be a need to obtain regulatory agency approval (including necessary permits) to construct and/or operate the facility as a whole or certain facility components. Facility components or apparatus that may require regulatory design review and permitting include: 1) storage tanks, associated piping, and other storage facilities for hazardous or radioactive materials; 2) construction activities near designated wetlands and the Peconic River; and, 3) air and liquid effluent release points. If an external review is required, the BNL submits review documents to the DOE Brookhaven Area Office (BAO) for subsequent transmittal to agencies such as the USEPA, New York State Department of Environmental Conservation (NYSDEC), and the SCDHS.

- Operational Readiness Reviews: Before a new or significantly modified facility is operated at BNL, an Operational Readiness Evaluation (ORE) is conducted (see ES\&H Standard 1.3.2). The ORE identifies the status or operational readiness of a facility before startup to ensure that all engineered safeguards and procedures are in place. The ORR also ensures that BNL line management is aware of their responsibility for environmental protection aspects of their operations.

\subsection{Process Review (Routine Processes and Experiments)}

From 1998 through 1999, BNL conducted a Process Evaluation Project (PEP) that provided a Laboratory-wide review of all experiments and industrial-type operations (see Goode 1998). The goal of the PEP was to identify all waste streams generated at the Laboratory to ensure that they are properly managed. Operations, experiments, and waste streams where equipment malfunctions and deterioration, operator errors, and discharges or emissions may potentially cause or may lead to releases of hazardous waste or pollutants to the environment, or that potentially pose a threat to human health or the environment, were identified during this evaluation.

As part of BNL's Work Planning initiative, a systematic program to review each existing research project was conducted to ensure all research activities were evaluated for environmental, safety and health impacts. Experiments were evaluated in accordance with ES\&H Standard 1.3.5. The Experimental Research Evaluation included the identification and 
evaluation of safety issues, environmental releases, waste generation, and provides for the identification of potential pollution prevention and waste minimization initiatives. The BNL experimental process inventory included approximately 1,900 experiments, including approximately 1,500 short-term experiments conducted at the National Synchrotron Light Source.

Industrial processes were evaluated by the preparation of process flow diagrams, written process descriptions, a regulatory determination of all processes (including air emissions and liquid effluents), identification of pollution prevention opportunities, and the identification of any assessment, prevention or control measures that should be considered. The PEP inventory numbers approximately 130 industrial processes, and includes typical industrial activities such as: machining and milling operations; photographic developing; vehicle maintenance, metal cleaning and plating; electronic assembly; utilities; and other site services.

The PEP also deployed environmental professionals known as Environmental Compliance Representatives (ECRs) to the field to proactively integrate environmental compliance and pollution prevention initiatives into Laboratory programs. The ECRs provide technical assistance to develop and implement environmental protection activities needed to ensure compliance with all applicable environmental requirements.

\subsection{Pollution Prevention and Waste Minimization Opportunities Assessments and Programs}

The goal of BNL's waste minimization/pollution prevention program is to prevent the generation of waste (solid, hazardous/mixed and radioactive), and minimize the generation of waste that cannot be prevented. BNL's Pollution Prevention Program Description outlines the Wmin/P2 program for the site (Goode 2000). The pollution-prevention program at BNL focuses on identifying and using cost-effective opportunities for waste reduction. Formal Pollution Prevention Opportunity Assessments, Waste Minimization Working Groups, and employee suggestions identify pollution prevention opportunities.

Those opportunities that are found to have environmental, economic and/or technical viability will be further pursued. An example of implementation of a pollution prevention approach that will help protect soils and groundwater is the LiveFire Range, where predominantly copper jacketed or Teflon coated bullets are used, and the bermed area is screened annually to remove spent bullets.

\subsection{Waste Management Program}

\subsubsection{Waste Management at the Point of Generation}

- Hazardous Waste Management: The Hazardous Waste Management Subject Area describes the requirements for establishing, operating, and closing accumulation areas for (RCRA) hazardous waste at BNL. Each generator of hazardous waste is required to collect and store all accrued hazardous waste in a Satellite Accumulation Area located at or near the point of waste generation. Before or when the quantity of hazardous waste at a satellite area reaches the maximum allowable quantity set forth in the Standard, the waste must be transferred to a department's approved 90-Day Accumulation Area. These waste materials are then transferred to the WMF.

- Radioactive Waste Management: The interim accumulation and disposition of radioactive and mixed wastes (i.e., wastes that contain both radioactive and RCRA defined hazardous constituents) are described in the Radioactive Waste Management Subject Area. Each generator of Mixed-LLRW is required to collect and store all accrued waste in a Satellite Accumulation Area located at or near the point of waste generation. Mixed-LLRW are considered RCRA hazardous wastes, and are stored in a segregated area in each department's 90-Day Accumulation Area. These waste materials are then transferred to the WMF. An environmental monitoring program has been established for the WMF as required by DOE Order 5820.2A and NYSDEC operating permit.

- Investigation Derived Wastes (IDW): Investigation Derived Wastes (IDW) are those wastes generated during environmental investigations. These wastes include contaminated subsurface soils brought to the surface during well drilling, contaminated groundwater pumped from wells during well development and sampling, 
decontamination fluids, and contaminated personal protective equipment. These wastes are managed in compliance with the substantive environmental protection requirements, as required by CERCLA.

\subsubsection{Centralized Waste Management}

- Waste Management Facility: In December 1997, BNL began operating a new Waste Management Facility (WMF) located close to the geographic center of the site. The WMF is the central receiving area for BNL's hazardous and radioactive waste, and is designed to safely handle, repackage, and temporarily store these waste materials prior to shipment to an off-site disposal or treatment facility.

- Solid Waste Disposal: BNL generates and accumulates non-hazardous solid wastes, which are shipped to the Brookhaven Town Landfill for recycling or disposal. BNL has not operated an on-site solid waste disposal facility (i.e., landfill) since 1990.

\subsubsection{Training}

- Waste Management Training Programs: Waste generators are trained on regulatory compliance and on the importance of preventing pollution and minimizing waste generation.

\subsection{Spill and Release Reporting and Response}

The BNL Emergency Plan (BNL, 1996b), the Spill Prevention, Control, and Countermeasures (SPCC) Plan (BNL, 2000), ES\&H Standards and Subject Areas have been developed in order to properly respond, to remediate and report spills of chemical or radioactive materials at the BNL site. Spill response procedures are described in SBMS Subject Area entitled Spill Response and the Environmental Services Division's Standard Operation Procedure RP-SOP-202. In response to requirements described in DOE Order 5000.3A, BNL also has established an Occurrence Reporting System that is used to report "Emergency Occurrences," "Unusual Occurrences," and "Off-Normal Occurrences" to the DOE, New York State, Suffolk County and other agencies. The procedures used for the BNL Occurrence Reporting and Processing System (ORPS) are described in ORPS Subject Area.

\subsection{Controlled Use of Fertilizers and Pesticides}

Except for limited and controlled use of fertilizers in the BNL Biology Department's greenhouses and agricultural fields, fertilizers are not applied on a routine basis at BNL. Fertilizers may occasionally be used during initial stages of grass growth (e.g., hydroseeding) following new construction projects. Insecticides, herbicides, and pesticides are occasionally used at the BNL site. As per regulatory requirements under the Federal Insecticide, Fungicide and Rodenticide Act (FIFRA), BNL maintains an inventory of all chemicals stored at various facilities, and records of all chemical applications. All applicator personnel are trained and certified by the NYSDEC for the safe handling and application of these chemicals, and each certified applicator submits an annual report to the NYSDEC that indicates the types and quantities of pesticides used during the year. In August 2001, the Cornell Cooperative Extension of Suffolk County conducted an independent assessment of the Laboratory's Pest Management Program (Sanok, 2001). The assessment found that the Laboratory's pest management programs constitute a "fully integrated pest management control strategy," which has resulted in the limited use of chemicals for pest management.

\subsection{Underground Injection Control}

The goal of the BNL Underground Injection Control (UIC) program is to prevent the discharge of contaminants that could jeopardize an underground source of drinking water. The Laboratory's program falls under the auspices of the EPA UIC program, wherein UIC devices are subject to inventory, and sampling, analysis, and closure, if necessary. The SCDHS has been the primary point of contact for enforcement and fieldwork for the EPA. The BNL site has only Class $\mathrm{V}$ injection wells, which are generically defined as wells used for injecting fluids, and are deeper than their widest surface dimension. BNL Class V injection wells include sanitary and other wastewater disposal systems including, but not limited to, drywells, cesspools, septic tanks, and leach fields. During the 1997 EPA Multimedia Audit, concerns were raised regarding the completeness of the Class V inventory on file with EPA. A revised inventory was prepared and 
submitted for EPA review and evaluation under an Administrative Order with the EPA Region II. In 1999 the BNL Plant Engineering Division evaluated all underground injection control wells to ensure that all storm water drainage systems and other drywells had been identified and included in the EPA inventory, and evaluate their need for continued use. As a result of this investigation, 54 UICs were identified as unnecessary and were closed in accordance with an EPA approved closure plan. The closure of Class V injection wells was coordinated with the SCDHS and EPA, and SCDHS cleanup guidelines were utilized to assess potential soil remediation requirements. The EPA issued BNL a UIC Area Permit in January 2001.

\subsection{Control of Toxic and Hazardous Materials Storage Facilities}

The 1987 Suffolk County/BNL Agreement requires the Laboratory to conform to the environmental requirements of Suffolk County Sanitary Code (SCSC) Articles 6, 7, 10, and 12. BNL has made significant progress toward bringing all toxic and hazardous materials storage facilities into compliance. By definition, storage facilities include above ground storage tanks, underground storage tanks, sumps, trenches, drum storage areas, piping systems, and closed-loop cooling water systems that contain or could contain toxic or hazardous liquids. Since 1987, 80 USTs have been excavated, and removed or properly abandoned in place. Of the remaining 32 USTs used for the storage of fuel oils, waste oils or gasoline products, all have been upgraded to meet SC Article 12 requirements for secondary containment, leak detection devices, and overfill alarms, where required. BNL plans to upgrade all remaining active storage facilities (i.e., drum storage areas and above ground storage tanks) by 2003. Inactive storage facilities located at the BGRR and WCF will be removed or abandoned as part of the ER Program.

\subsection{Wellhead Protection for Potable Supply Wells}

The 1986 Amendments to the Safe Water Drinking Act (SWDA) authorized states to develop Wellhead Protection Programs that were designed to protect areas surrounding drinking water supply wells against contaminants that may have adverse effects on human health. Congress amended the SDWA in 1996, and required states to evaluate all sources of water (e.g., well, stream, lake or reservoir) that are used to supply public drinking water. Source Water Assessments (SWA) are required to determine where the public drinking water originates, list actual and possible sources of contamination located within the source area, and evaluate the likelihood that a source could be contaminated. In accordance with the SDWA requirements, BNL developed a Source Water Assessment for Drinking Water Supply Wells (Bennett et al., 2000).

The Source Water Assessment concluded that the BNL water supply system meets all water quality standards and has sufficient pumping and storage capacity to meet current and anticipated future operational demands. However, because BNL's water supply is drawn from the shallow Upper Glacial aquifer, water supply operations are susceptible to contamination. Although a number of BNL's water supply wells were impacted by VOC contamination in the late 1980 s, recent routine analysis of water samples from BNL's supply wells indicate that no drinking water standards have been reached or exceeded. The high quality of the water supply indicates that the operational and engineered controls implemented over the past ten years have effectively protected the quality of the water supply.

As part of the assessment, source water areas for each drinking water supply well were identified using the BNL Regional Groundwater Model. The extent of these source areas was compared to the inventory of known and potential sources of contamination. This evaluation concluded that the source water for BNL's Western Well Field (comprised of Supply Wells 4, 6, and 7) has relatively few threats of contamination and that identified potential sources are already being carefully managed (Figure 10). The source water for BNL's Eastern Well Field (comprised of Supply Wells 10, 11 , and 12) has moderate threats to water quality, primarily from several existing volatile organic compound and tritium plumes. The g-2 Tritium Plume and portions of the Operable Unit III volatile organic plume fall within the delineated source water area for the Eastern Well Field. In addition, portions of the much slower migrating strontium- 90 plumes associated with the Brookhaven Graphite Research Reactor, Waste Concentration Facility and Building 650 lie within this source area. However, the rate of travel in the aquifer for strontium- 90 is about one-twentieth of that for tritium and volatile organic compounds. Therefore, the time of travel to the supply wells for the strontium- 90 plumes is significantly greater than five years. The Laboratory has been carefully monitoring plume migration, and has made adjustments to water supply operations. 


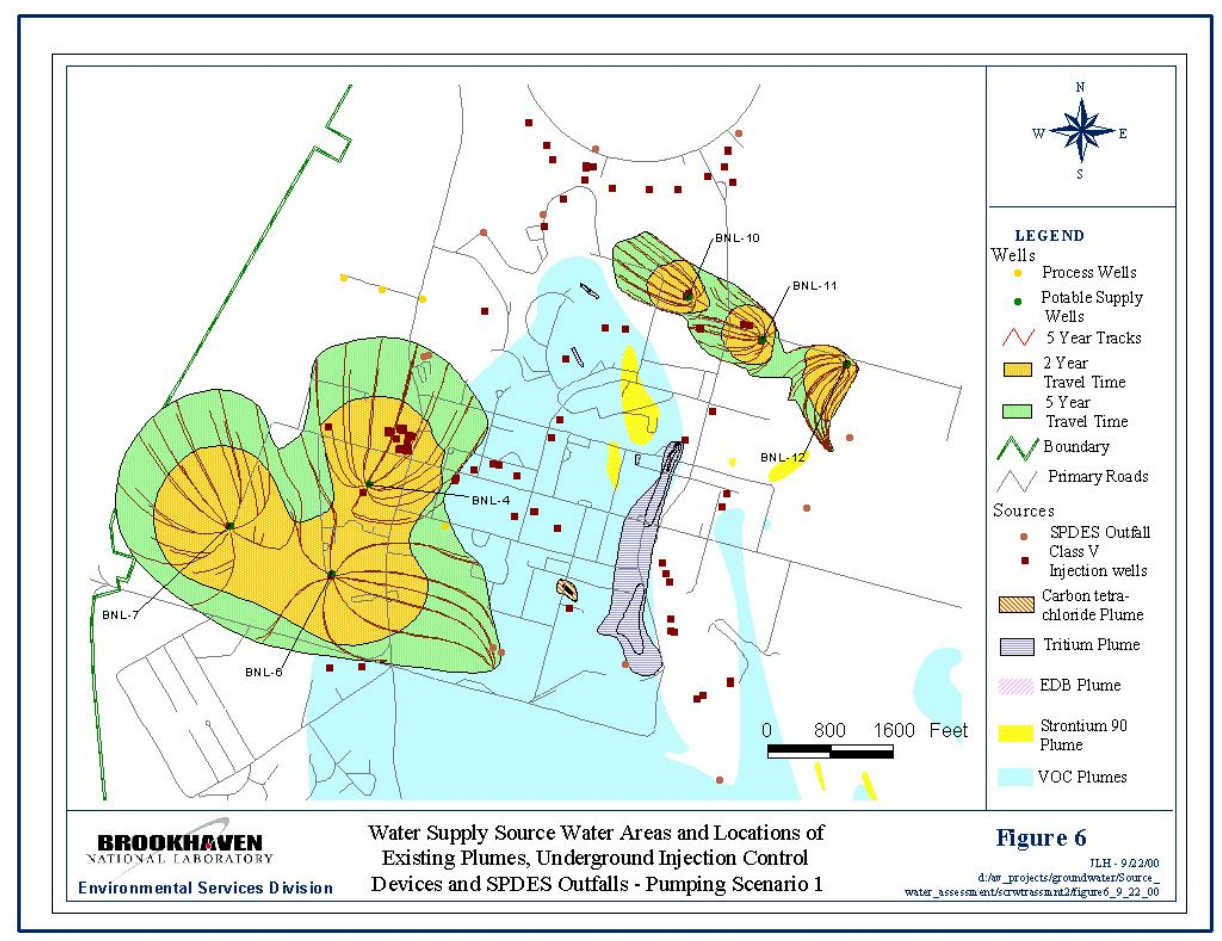

Figure 10. Example of Source Water Protection Area at BNL

\section{MONITORING}

BNL has an extensive groundwater monitoring program that is designed to: 1) track existing contaminant plumes; 2) evaluate the effectiveness of groundwater remediation systems; 3) evaluate the effectiveness of engineered and operational controls at active research and support facilities; and 4) monitor changes in groundwater flow directions and velocities. Elements of this program include: installation of monitoring wells, planning and scheduling, quality assurance, sample collection, sample analysis, data analysis and interpretation, and reporting. The groundwater monitoring program is implemented by two organizations --the ES program and the ER program. These programs are coordinated to ensure completeness and to prevent any duplication of effort in the installation and abandonment of wells, and the sampling and analysis of groundwater. The BNL monitoring well network consists of over 1100 wells that are located both onsite and offsite.

\subsection{BNL Groundwater Monitoring Programs - Design and Implementation}

DOE Order 5400.1, Chapter IV - Environmental Monitoring Requirements states that "Groundwater that is or could be affected by DOE activities shall be monitored to determine the effects of operations on groundwater quality and quantity and to demonstrate compliance with DOE requirements and applicable federal, state and local laws and regulations." The goals of the monitoring element of the GPMP are to:

- Comply with regulatory requirements for groundwater monitoring (see Appendix B for a summary of drivers);

- Obtain data for the purpose of determining baseline groundwater quality and quantity conditions;

- Identify existing and potential groundwater contamination sources and maintain surveillance of these sources; 
- Provide data to permit the early detection of groundwater contamination;

- Provide a reporting mechanism for communicating the groundwater quality information;

- Provide data upon which decisions can be made regarding management and protection of groundwater resources and the need for remedial actions;

- Demonstrate compliance with and implementation of all applicable regulations and DOE Orders.

- Evaluate the long-term effectiveness of landfill capping systems;

- Evaluate the effectiveness of groundwater remediation systems, and provide the data necessary for decisions on the current and future operations of these systems;

- Provide data to evaluate natural attenuation and other non-evasive remedial actions; and,

- Provide a status report of the nature and extent of identified plumes.

\subsection{Groundwater and Drinking Water Monitoring Standards}

As noted previously, the groundwater beneath the BNL site is considered by NYS as Class GA groundwater. The best usage of Class GA groundwater is as a source of potable water supply. As such, federal drinking water standards, NYS Drinking Water Standards (NYS DWS), and NYS Ambient Water Quality Standards (NYS AWQS) for Class GA groundwater have been used as groundwater protection and remediation goals for the sole source aquifer underlying BNL. The BNL groundwater surveillance program uses wells (which are not utilized for drinking water supply) to monitor research and support facilities where there is a potential for environmental impact, or in areas where past waste handling practices or accidental spills have already degraded groundwater quality. BNL evaluates the potential impact of radiological and non-radiological levels of contamination by comparing analytical results to NYS and DOE reference levels and background water quality levels. Non-radiological data from groundwater samples collected from surveillance wells are usually compared to NYS Ambient Water Quality Standards (6 NYCRR 703.5). Radiological data are compared to the NYS DWS (for tritium and strontium-90), NYS AWQS (for gross alpha, gross beta and radium 226/228), and SDWA/DOE DCGs (for determining the $4 \mathrm{mrem} / \mathrm{yr}$ dose for other beta/gamma-emitting radionuclides). Contaminant concentrations that are below these standards are also compared to background values to evaluate the potential effects of facility operations. The detection of low concentrations of facility-specific VOCs or radionuclides may provide important early indications of a contaminant release, and allow for the timely investigation into the identification and remediation of the source.

\subsection{Monitoring Potable Water Supplies}

For drinking water supplies, the federal maximum contaminant levels (MCLs) set forth in 40 CFR 141 (primary MCLs) and 40 CFR 143 (secondary MCLs) apply. In addition, DOE Order 5400.5, Radiation Protection of the Public and Environment, establishes Derived Concentration Guides (DCGs) for radionuclides not covered by existing federal or state regulations.

In NYS, the SDWA requirements pertaining to the distribution and monitoring of public water supplies are applicable to any water supply that has at least five service connections or regularly serves at least 25 individuals. The Laboratory supplies water to a population of approximately 3,500 employees and visitors and must, therefore, comply with these regulations. The SCDHS - Bureau of Drinking Water specifies the annual minimum monitoring requirements for all potable-water suppliers.

BNL prepares an annual Potable Water System Sampling and Analysis Plan that outlines sampling procedures and schedules for monitoring the BNL's potable water supply system. Routine monitoring of the potable wells and the potable-water distribution system by BNL exceeds the prescribed minimum monitoring requirements. The monitoring program consists of: monthly bacteriological analyses; quarterly analyses for Principal Organic Compounds (POCs); annual analysis for Synthetic Organic Compounds (SOCs) and pesticides; semi-annual inorganic chemicals analyses; and 
annual analyses of micro-extractables and asbestos. Potable water samples are collected by BNL personnel, and are analyzed by New York State Department of Health (NYSDOH) certified contractor laboratories using standard USEPA methods. BNL prepares monthly Water System Operations Reports, which are submitted to the SCDHS - Bureau of Drinking Water. These reports include a summary of all analytical data. In addition to the SCDHS requirements, BNL maintains a supplemental sampling and analysis program for the BNL potable well system that includes more frequent analyses for radionuclides.

\subsection{Active Facility (Non-CERCLA) Monitoring}

One of the lessons learned from the 1997 discovery of the tritium release at the High Flux Beam Reactor was the need for improved monitoring of active facilities that have the potential to impact groundwater quality. The Groundwater Monitoring Improvements Project examined the operations of active research and support facilities, and re-examined historical groundwater data to identify potential contaminant source areas (non-CERCLA) that may have been overlooked or given a low priority due to apparently low levels of contamination. This evaluation was performed concurrently with the 1997 Facility Review Project (Royce, 1997; Royce and Collins, 1997). Known or suspected contaminant source areas that have been or are currently being studied, closed or remediated under the IAG were not part of the review.

The Brookhaven National Laboratory Groundwater Monitoring Improvements Plan (Paquette, 1998) provided a summary review of: 1) the operational history of each facility requiring improvements in its groundwater monitoring program; 2) identification of potential contaminant source areas (e.g., underground storage tanks and beam stop areas); 3) review of the historical and current groundwater monitoring programs and available groundwater data; 4) recommendations for necessary groundwater monitoring upgrades or improvements at each facility; and, 5) a prioritized schedule for the installation of new wells.

An important premise of the BNL GPMP is that groundwater monitoring is, in itself, not protective of groundwater quality. Rather, groundwater resources can only be adequately protected by the prevention and/or timely remediation of future contaminant releases (see protection programs presented in Section 5). However, groundwater monitoring is one means to evaluate the effectiveness of prevention programs. In 1999 and 2000, 85 new wells were installed as part of the Groundwater Monitoring Improvements Project to improve BNL's ability to monitor groundwater quality near active research and support facilities. The improved groundwater monitoring network has provided BNL with timely information related to potential impacts that facility operations may have on groundwater quality, and on the adequacy of its pollution prevention programs. The improved monitoring program allowed BNL to identify groundwater impacts at three AGS experiment areas (g-2, former E-20 Catcher, and former U-Line Beam Stop), BLIP, Service Station, and the BNL vehicle maintenance facility. If unexpected levels of contamination are detected, appropriate investigations into the source of the contamination and/or remedial measures can be taken. BNL has developed a Groundwater Protection Contingency Plan that outlines the process used by BNL management to respond to the unexpected detection of contaminants in groundwater.

Assessment of the adequacy of the BNL groundwater monitoring well network is an ongoing process. The need for additional monitoring wells at either new or significantly modified facilities is identified during the BNL Facility Design Review process (see Section 5.5). The currently active BNL research and support areas that require routine surveillance of groundwater quality as required by DOE Order 5400.1 are described below. The wells used to monitor these facilities include new wells installed as part of the Groundwater Monitoring Improvements Project and appropriately located older wells.

The details on the monitoring objectives and decisions being supported with the monitoring data are provided in the BNL Environmental Monitoring Plan CY 2002 Update (BNL, 2002). An overview of each groundwater monitoring project follows. 


\subsubsection{Monitoring of Potential Radiological Source Areas}

- AGS Area: The AGS groundwater monitoring program consists of monitoring approximately 45 shallow wells. These wells are used to evaluate the effectiveness of engineered controls (e.g., landfill type impermeable caps) established for activated soil shielding areas near AGS beam targets and stops.

- BLIP Facility: The BLIP groundwater monitoring program consists of monitoring seven shallow Upper Glacial aquifer wells. These wells are used to evaluate the impact of activated soils that surround the BLIP target vessel, and to evaluate the effectiveness of previously implemented remedial measures (e.g., sealing and capping of the area surrounding the BLIP, improved storm water drainage, operational modifications, and soil grouting).

- RHIC Area: The RHIC groundwater monitoring program consists of monitoring 13 shallow Upper Glacial aquifer wells installed near the RHIC collimator and beam stop areas. The wells are used to evaluate the effectiveness of the landfill-type caps constructed over these potentially activated soil shield areas.

- BMRR Area: The BMRR groundwater monitoring program consists of monitoring five shallow Upper Glacial aquifer wells. The wells are used to verify that operational and engineering controls are effective in preventing future environmental releases.

- Building 830: The Building 830 groundwater monitoring program consist of monitoring three shallow Upper Glacial aquifer wells. The wells are used to evaluate the impact of small-scale historical releases of cobalt- 60 and volatile organic compounds.

- STP Area: The STP groundwater monitoring program consists of the monitoring of nine shallow Upper Glacial aquifer wells located near the STP's filter beds and emergency hold-up ponds. The wells are used to verify that operational and engineering controls and effluent monitoring systems are effective in preventing future environmental releases.

- Waste Management Facility: The Waste Management Facility groundwater monitoring program consists of eight shallow to middle Upper Glacial aquifer wells. The wells are used to verify that the facility's engineering and operational controls are effective in preventing environmental releases.

\subsubsection{Monitoring of Potential Chemical Source Areas}

- Motor Pool: The Motor Pool groundwater monitoring program consists of monitoring seven shallow Upper Glacial aquifer wells to evaluate the potential impact of several historical solvent and oil spills and to verify that engineering and operational controls for USTs containing gasoline products and waste motor oil are effective in preventing environmental releases.

- Gasoline Station: The Gasoline Station groundwater monitoring program consists of monitoring five shallow Upper Glacial aquifer wells. The wells are used to verify that engineering and operational controls for USTs containing gasoline and waste motor oil products are effective in preventing environmental releases.

- Major Petroleum Facility: The MPF groundwater monitoring program was established in 1986 as part of the NYSDEC licensing requirements for the facility. The program consists of monitoring eight shallow Upper Glacial aquifer wells designed to detect both free product and dissolved hydrocarbon products.

- Live Fire Range: The Live-Fire Range groundwater monitoring program consists of monitoring two shallow Upper Glacial aquifer wells. The wells are used to verify that range operations are not impacting groundwater quality. 
- Shotgun Range: The Shotgun Range groundwater monitoring program consists of monitoring three shallow Upper Glacial aquifer wells. The wells are used to verify that lead shot deposited on the surface of the range is not impacting groundwater quality.

- STP Area: (see 6.4.1 above).

- Waste Management Facility: (see 6.4 .1 above).

- Greenhouse Areas: The Biology Department Greenhouse area groundwater monitoring program consists of monitoring two shallow Upper Glacial aquifer wells. These wells are used to evaluate the potential impacts to groundwater from historical use of pesticides and metals in the greenhouses.

\subsection{Environmental Restoration Groundwater Monitoring Program (CERCLA)}

Groundwater monitoring for the CERCLA driven cleanup program is deployed on a project specific basis (i.e. Operable Unit or treatment systems within an Operable Unit). The monitoring is coordinated and integrated within an umbrella project called the Sitewide Groundwater Monitoring Program. In 2001 this program managed 19 individual monitoring projects that entailed 2,180 separate sampling events at 563 wells. In addition, quarterly groundwater level and background groundwater quality is monitored. In general, these monitoring projects serve one or more of the following functions:

- Track a dynamic groundwater cleanup problem when designing and constructing groundwater treatment systems:

Better characterizes the plume to support the cleanup design process and tracks its movement on a short time basis until the treatment system is in operation

- Measure the performance of the groundwater cleanup efforts:

Source Removal Effectiveness: Includes monitoring of wells installed to verify that remediation projects such as the capping of previously used landfills are performing to design specifications;

Treatment System/Hydraulic Containment Effectiveness: Includes monitoring the performance of active pump-and-treat systems to verify that they are capturing and removing contaminants as designed; and

Attenuation of low levels of contamination in the aquifer at acceptable rates to protect human health and the environment

- Protect public health and the environment during the cleanup period:

Outpost Monitoring: Consists of wells located downgradient of the leading edge of contaminant plumes. Sampling of these wells provides for early warning of the arrival of the leading edge of the plume.

- Trigger early action and communication should the unexpected happen.

The details on the monitoring objectives and decisions being supported with the monitoring data are provided in the BNL Environmental Monitoring Plan CY 2002 Update (BNL, 2002). An overview of each CERCLA driven groundwater monitoring project follows.

\subsubsection{Background Monitoring}

Provides information on background groundwater quality for the BNL site. Background quality is defined as the quality of groundwater that is completely unaffected by BNL operations. Analytical parameters for groundwater samples also include the contaminants of concern (COC) that have been identified through the groundwater characterization work performed as part of the various remedial investigations and removal actions at BNL. The site background monitoring program provides groundwater quality data from a network of 13 wells located in the northern portion of the site (and 
off-site to the north), upgradient from the developed areas of BNL (central portion of the BNL site). These wells are also situated downgradient of potential contaminant sources to the north of BNL.

\subsubsection{Operable Unit I}

There are two groundwater monitoring projects within OU I, they are

Current Landfill: The Current Landfill operated from 1967 through 1990. It was used to dispose of putrescible waste, sludge containing precipitated iron from the BNL Water Treatment Plant, and anaerobic digester sludge from the sewage Treatment Plant. The latter contained low concentrations of radionuclides, and possibly metals and organic compounds. Limited quantities of laboratory wastes containing radioactive and chemical material were disposed at the landfill. During its operating life, this landfill was unlined and did not have a leachate control system.

The current Landfill was capped in the fall of 1995 in accordance with 6 NYCRR Part 360. This cap consists of a geotextile fabric overlain by a 12-inch gas-venting layer followed by a 40 -millimeter double-sided textured geomembrane topped with a 24-inch thick protection layer and 6 inches of topsoil. Additional information and details on the landfill construction and maintenance can be found in the Construction Certification Report for the Former Landfill (CDM 1995). The Current Landfill monitoring program, consisting of a network of eleven monitoring wells located immediately adjacent to the landfill was designed to provide post-closure monitoring as per NYSDEC requirements. These wells are used to determine the cap's effectiveness in preventing the continued leaching of contaminants from the landfill, and to document the anticipated long-term improvements to groundwater quality.

OU I South Boundary: This monitoring directly supports the operation and performance assessment of the RA V groundwater treatment system. The RA V system is a conventional pump and treat system with a capacity of $700 \mathrm{gpm}$. Its 62 monitoring wells ( 15 of which also are used for the Current Landfill and OU III North Street monitoring programs) are used to assess the control and cleanup progress of a commingled VOC plume from several sources including the Current Landfill and former Hazardous Waste Management Facility. Because the plume also contains low levels of radionuclides, Sr-90 and tritium are also monitored to ensure they do not exceed drinking water standards. The well network was organized into core, perimeter and bypass wells.

\subsubsection{Operable Unit III}

There are fourteen groundwater monitoring projects within OU III. They are

Carbon Tetrachloride Pump and Treat System: A 1,000-gallon underground storage tank (UST) utilized to store carbon tetrachloride at the former Chemistry Department Complex during the 1950s was removed in April 1998. At that time, carbon tetrachloride within the UST was apparently inadvertently released. Plume characterization was conducted during the summer and fall of 1998. A groundwater remediation system, consisting of three shallow extraction wells and carbon treatment, was constructed and began operation during the fall of 1999. Fourteen monitoring wells are used to assess the effectiveness of this source control action. The well network was organized into core, perimeter, sentinel and bypass wells.

Building 96 In-Well Air Stripping System: The Building 96 groundwater treatment system is designed to treat a source area of VOCs (primarily PCE). It consists of four recirculation treatment wells. The monitoring network of 17 wells was designed to monitor the PCE plume originating in this source area, and the effectiveness of a groundwater remediation system.

Middle Road Pump and Treat System: The OU III Middle Road pump and treat system was designed to capture contamination consisting of VOCs in the Upper Glacial aquifer upgradient of the BNL south property boundary. The OU 
III Middle Road groundwater extraction and treatment system includes six extraction wells. Extracted groundwater is treated via air stripping and recharged upgradient of the plume. The system has been in operation since the fall of 2001 . The groundwater monitoring supports the operation and performance assessment of the groundwater treatment system. The Middle Road Monitoring Program consists of a network of 26 toring wells.

South Boundary Pump and Treat System: Seven groundwater extraction wells provide hydraulic control of the VOC plume along the south property boundary of BNL. It began operation in July 1997. Groundwater is extracted at a total maximum flow rate of about $750 \mathrm{gpm}$. VOC concentrations in groundwater along BNL's southern property line are stratified vertically and horizontally. The monitoring well network consists of 40 wells and was designed to monitor the VOC plume(s), as well as the effectiveness of the groundwater remediation system.

Industrial Park In-Well Air Stripping System: The OU III Industrial Park system was designed to contain and remediate the portion of OU III plume existing between BNL's southern boundary and the southern boundary of the Parr Industrial Park. The monitoring well network consists of 39 wells and is designed to monitor the VOC plume(s), and the effectiveness of the in-well groundwater treatment system.

Former Landfill: The Former Landfill monitoring well network of eight wells was designed in accordance with postclosure requirements specified in 6 NYCRR Part 360, Solid Waste Management Facilities, dated December 31, 1988. The program was started after the Former Landfill was capped, and will verify whether the cap effectively prevents the continued leaching of contaminants from the landfill, and document anticipated long-term improvements to groundwater quality. A Five-Year Evaluation Report (Grosser, 2002) was prepared and submitted in March 2002 as per the requirements of 6 NYCRR Part 360 Section 2.1.5, Solid Waste Management Facilities (effective December 31, 1988). This report summarized the status of groundwater quality in the vicinity of the Former Landfill and presented conclusions and recommendations regarding the effectiveness of the cap and future monitoring efforts.

Off-site Monitoring: The OU III Offsite Groundwater Monitoring Program consists of twenty wells that were installed primarily during the OU III RI. These wells are used to track the plume core or perimeter in offsite areas and to serve as sentinel wells for the leading edge of the plume. Most of these wells will be folded into the groundwater monitoring programs associated with the planned Long Island Power Authority and Brookhaven Airport (LIPA and Airport) remediation systems as they come on line.

North Street Monitoring: The North Street (formerly known as OU I/IV) monitoring program addresses both a VOC plume that is primarily south of the BNL boundary and the issue of radiological contaminants that may have been introduced to groundwater in the OU IV portion of the site (particularly the Building 650 and 650 Sump Outfall areas). The planned North Street and the Airport Groundwater Remediation Systems will address the VOC plume in this area. A network of 24 monitoring wells is used to monitor the downgradient portion of the OU IV, Former Landfill, Animal/Chemical Pits, and Glass Holes VOC plumes and potential radiological contamination originating in these areas. Additionally, wells sampled under the OU III South Boundary and Industrial Park Programs are utilized for mapping purposes with respect to this plume. Additional wells will be installed during 2002/2003 in association with the construction of the groundwater treatment system.

Western South Boundary Groundwater Treatment System: The Western South Boundary pump and treat system is designed to capture the higher concentrations of VOCs in the Upper Glacial aquifer along the western portion of the BNL south property boundary. This system will capture and remediate a portion of the OU III VOC plume to reduce future offsite migration of the contamination and discharge of the VOC plume to the Carmans River. This system will be operational in the summer of 2002. The wells are sampled quarterly and analyzed for VOCs. Sixteen groundwater monitoring wells are in place to monitor the VOC plume and the effectiveness of the groundwater remediation system.

Central Monitoring: The OU III Remedial Investigation identified several low-level VOC source areas and non-point contaminant sources within the developed central areas of the BNL Site. Since these sources, which include spills within the AGS Complex, at the storage area for site maintenance equipment (Building 208) and other sources, are not significant enough to warrant a dedicated monitoring program, they are monitored under the OU III Central project. This 
project includes two monitoring wells, located near the BNL site boundary, that serve as sentinel wells for the Suffolk County Water Authority (SCWA) William Floyd Parkway wellfield.

The monitoring well network established to check the relatively low-level VOC contamination in the central areas of the site is comprised of 22 wells. Seven of these wells have transitioned into other programs (primarily OU III Middle Road) for 2002. The locations provide data on groundwater quality near the source areas that aid in defining the VOC plumes, which extend downgradient from this area of the site. This network also is supplemented by data from Environmental Surveillance program wells that monitor active research and support facilities.

HFBR Tritium: In late 1996, tritium was detected in wells near the High Flux Beam Reactor (HFBR). The source of the release was traced to the HFBR spent fuel pool. A monitoring well network of 141 wells was designed to follow the extent of the plume, monitor the source area, and evaluate the effectiveness of the groundwater remediation system. Due to the closeness of the HFBR to artificial pumping and recharge locations, the plume is subjected to changing hydraulic stresses, which have warranted an extensive monitoring network. BNL's Regional Groundwater Model was utilized to assist with the placement of the wells. This program is described in the OU III HFBR Downgradient Monitoring Plan (BNL, July 2001).

BGRR/Waste Concentration Facility Monitoring: The OU III Brookhaven Graphite Research Reactor (BGRR)/Waste Concentration Facility (WCF) project monitors the extent of strontium-90 plumes in groundwater. These plumes are the result of historical releases from these facilities. A network consisting of 57 monitoring wells was designed to monitor the Sr-90 plumes associated with the BGRR, WCF, and Pile Fan Sump. Fourteen wells monitored under this program also are sampled under the AOC 29 HFBR Tritium program; sampling events are coordinated between the two programs to eliminate any duplication of effort. This monitoring tracks the movement and status of the plume in anticipation of a future groundwater treatment system in this area.

Chemical/Animal Holes: Between 1960 and 1966, waste, glassware containing chemical and radioactive waste, and animal carcasses containing radioactive tracers was disposed in shallow pits in an area directly east of the Former Landfill. Used glassware continued to be disposed in shallow pits directly north of this area from 1966 through 1981. Remediation of the impacted soil in the Chemical/Animal Holes area, including waste excavation, treatment and disposal, was completed in September 1997. The monitoring well network for the Chemical/Animal Holes consists of 24 wells. These wells are used to monitor the migration and attenuation rate of the Sr-90 plume that resulted from these "pits" and to establish a baseline of data to support a pilot project to treat the $\mathrm{Sr}-90$ in the groundwater. This pilot will commence in mid-2002.

South Boundary Radionuclide Monitoring: The South Boundary Radionuclide Monitoring Program was created in late 2001 as a result of developing groundwater data quality objectives (DQOs) for the OU III South Boundary Remediation System and the OU III Western South Boundary Remediation System. The DQOs concluded that radionuclide monitoring was not required to evaluate the effectiveness of these systems. However, it was determined that such analyses were warranted to confirm that groundwater impacted by radionuclides is not migrating offsite. The sampling will continue in conjunction with the South Boundary and Western South Boundary programs. The south boundary of the eastern portions of the site are monitored for radionuclides as part of the OU I South Boundary, EDB, and OU V Sewage Treatment Plant groundwater monitoring programs. A network of 31 monitoring wells incorporates wells also sampled as part of the OU III South Boundary and OU III Western South Boundary Programs. The wells are located along the southern property boundary.

\subsubsection{Operable Unit IV}

There are two groundwater monitoring projects with in OU IV. They are 
Air Sparge/Soil vapor Extraction Remediation System (AOC 5): In 1977, a 23,000 to 25,000 gallon mixture of Number 6 fuel oil and mineral spirits was released from a ruptured pipe used to transfer the contents from a UST to aboveground storage tanks at the Central Steam Facility (CSF). The primary chemical contaminants in the OU IV plume near the 1977 spill site are TCA, PCE, DCE, TCE, toluene, ethylbenzene, and xylenes. In addition, several small spills of Number 6 fuel oil from the CSF fuel unloading area were documented between 1988 and 1993; it also is suspected that small volumes of solvents, such as PCE, were released to the ground near the CSF.

Air sparge with soil vapor extraction was selected as the remedy for soil and groundwater contaminated with VOCs underlying OU IV. The AS/SVE system has been operating since November 1997. Performance goals for soil cleanup were achieved in 1998 while performance goals were met in August 2000 for groundwater. Subsequently, a formal petition for shutdown was submitted to EPA and NYSDEC and approval for shutdown was received in January 2001. The system was shutdown on January 10, 2001. However, following the shutdown, groundwater results were received for one well located near the spill site showed a rebound in several VOC parameters (indicative of fuel oil). Because of this, pulsing of the AS/SVE system was initiated on a weekly basis in February 2001.

A network of 21 wells was designed to monitor the effectiveness of the groundwater remediation system. Locations were selected using BNL's Regional Groundwater Model. During planning for placing the wells, the proximity of the RA V and HO Recharge basins was considered, along with their associated effects on local patterns of groundwater flow. Eight of the wells sampled under this program also are utilized for monitoring for radionuclide contamination originating from Building 650's Sump Outfall Area. The two programs coordinate sampling to eliminate any duplication of effort.

Building 650 and 650 Sump Outfall (AOC 6): The OU IV AOC 6 Remedial Action monitoring program consists of monitoring wells located in the vicinity of the Building 650 Reclamation Facility and the 650 Sump Outfall Area. Strontium- 90 is the primary contaminant of concern in this area. A monitoring network was designed to clarify the extent of Strontium-90 contamination originating from the area of the Building 650 Sump Outfall. The network consists of 22 wells (eight of which are used for the OU IV AOC 5 program) located to define the limits of Sr-90 contamination, monitor it natural attenuation, and serve as an early warning system for the downgradient migration of the plume.

\subsubsection{Operable Unit V}

Historically, the BNL Sewage Treatment Plant (STP) received discharges of contaminants from routine operations at the facility. Releases of contaminants, in particular VOCs, metals and radionuclides, to groundwater occurred via the STP sand filter beds and discharges to the Peconic River. In addition, trace levels of pesticides have been detected in some wells. The OU V project monitors the identified groundwater contamination in the eastern site boundary and off-site areas.

A monitoring network of 34 wells was designed to follow groundwater contamination downgradient of the STP at the boundary and offsite. Sentinel wells were installed downgradient of the leading edge of the offsite VOC plume. BNL's Regional Groundwater Model was used to aid in placing these wells. These data are used to monitor the natural attenuation of the plume and to provide early warning of its movement.

\subsubsection{Operable Unit VI}

The OU VI EDB Program monitors the extent of an EDB plume in groundwater. EDB was used during the 1970s as a fumigant for the BNL Biology Department's agricultural fields located in the southeastern portion of the site. In 1995 and 1996, low levels of EDB were detected in groundwater near the fields. Higher levels of EDB were detected migrating toward the southern BNL site boundary and off-site to the south. The depth of the plume increased within the Upper Glacial aquifer to the south. A groundwater remediation system to address the off-site EDB plume is currently being designed and system operation is planned to begin during calendar year 2002.

A network of 28 wells monitor the EDB plume from the source area in the Biology Department's agricultural fields to locations on private property south of North Street. Additional monitoring wells will be installed as part of the pre-design characterization of a planned pump and treat system in 2002. 


\subsection{Liquid Effluent Monitoring Program}

Liquid effluent monitoring is performed for radiological and non-radiological effluent streams. Because potential chemical and radioactive liquid waste discharged to the sanitary system and recharge basins can quickly degrade surface water and groundwater (Upper Glacial aquifer) quality, BNL's effluent monitoring and control system is a key element in the overall Groundwater Protection Program. These effluents are monitored to determine compliance with applicable DOE Orders, regulatory and permit requirements, and to evaluate the effectiveness of effluent treatment and control systems. A detailed description of the monitoring program is presented in the BNL Environmental Monitoring Plan (BNL, 2002).

- Sewage Treatment Plant: The STP discharge to the Peconic river is governed by a NYSDEC State Pollution Discharge Elimination System (SPDES) permit. BNL's STP treated effluent is discharged to the Peconic River at SPDES permitted outfall number 001. In accordance with the BNL SPDES permit, twenty-seven (27) parameters are reported in the monthly Discharge Monitoring Report (DMR), which is submitted to both the NYSDEC and the SCDHS. BNL personnel collect the samples in accordance with BNL's Standard Operating Procedures (SOPs) and Quality Assurance (QA) protocols. Seventeen parameters including nitrogen, metals, organic, biological oxygen demand $\left(\mathrm{BOD}_{5}\right)$, total suspended solids, fecal coliform, and cyanide are analyzed by NYSDOH-certified contractor laboratories. The remaining parameters (flow, settleable solids, residual chlorine, and $\mathrm{pH}$ ) are recorded and analyzed by the STP operators).

- Recharge Basins: The Laboratory maintains seven recharge basins for the discharge of process-cooling waters, storm-water runoff, and, in the case of recharge basin HX (Outfall 007), water-filter backwash from the WTP. Cooling water is discharged to basins HN (Outfall 002), HO (Outfall 003), HP (Outfall 004), HS (Outfall 005), and HT (Outfalls 006A and 006B); storm water is discharged to basins HN, HO, HS, HT, HW (Outfall 0008) and the CSF (Outfall 010). The SPDES permit requires that BNL monitor these discharges monthly for flow, $\mathrm{pH}$, and oil and grease, and quarterly for certain metals and VOCs.

\subsection{Monitoring Well Installation, Maintenance and Abandonment}

- Monitoring Well Installation: The determination of the effects of BNL operations on groundwater quality can only be accomplished through the proper installation and management of an established monitoring well network. Monitoring well installations at BNL are coordinated by ER and ES project hydrogeologists. Procedures for the installation of most monitoring wells are described in BNL Standard Operating Procedure EM-SOP-102, Installation of Groundwater Monitoring Wells. Procedures for the installation of temporary wells (e.g., Geoprobe and vertical profile wells) are described in BNL Standard Operating Procedure EM-SOP-305, Collection of Groundwater Samples Using Temporary Wells. These procedures are consistent with the well installation guidelines required by the USEPA and the NYSDEC for both CERCLA and RCRA groundwater investigations. All wells are installed by NYS licensed well drilling contractors, and well installation procedures are overseen by professional geologists/hydrogeologists.

- Well Maintenance: Proper well maintenance is essential to optimize the functioning of the wells, and to ensure the collection of representative groundwater samples and accurate groundwater elevation data. During groundwater sampling and water level activities, the condition of each monitoring well is examined. Problems such as broken or non-operating locks, damaged or missing well identification tags, damaged protective casings or well casings, and inoperable sample pumps are documented in field notes and reported to the project manager/hydrogeologist. Typically, most repairs are minor, and are performed by BNL sampling personnel. Repairs to protective casing or well casings are usually performed by NYS licensed well drilling contractors. Procedures for inspecting and maintaining groundwater monitoring wells are described in BNL Standard Operating Procedure EM-SOP-103, Maintenance of Groundwater Monitoring Wells.

- Well Abandonment: Monitoring wells that are either damaged beyond repair or determined to be of no future use for the collection of groundwater samples or water level data are properly abandoned. Abandonment procedures are 
outlined in BNL Standard Operating Procedure 104, Abandonment of Monitoring Wells, Supply Wells and Remediation Wells. Plans for all well abandonment projects are coordinated and approved by both the ER and ES Project hydrogeologists. Documentation for all well abandonment projects is maintained in the BNL Environmental Information Management System (EIMS). BNL develops plans to abandon monitoring wells that are no longer needed using the DQO process.

\subsection{Sample Collection, Analysis and Data Management}

- Sample Collection: The methods used in the collection of groundwater samples, surface water samples, and hydrogeologic measurements (i.e., geological data and water level measurements) are described in the Environmental Monitoring Standard Operating Procedures and in project-specific work plans. Sample and measurement requirements are described in project-specific Sampling and Analysis Plans and the annual BNL Environmental Monitoring Plan (see BNL, 2002). At the time of collection in the field, sample procedures, observations and other pertinent information are documented in bound field logbooks and standardized forms. All sample identification numbers are documented on standardized BNL Chain-of-Custody forms (EM-SOP-109).

- Sample Analysis: The specific analytical methods used for the BNL ER and ES Programs are listed in the annual Environmental Monitoring Plan (BNL, 2002) and other project-specific sampling and analysis plans. EPA approved methods are used for performing analyses. For the ER Program, most analyses are performed by NYSDOH certified contractor laboratories. For the ES Program, the BNL Analytical Services Laboratory (ASL) performs most analyses. The ASL is certified by the NYSDOH for each of the analyses performed. However, samples collected for compliance with SPDES or other regulatory permits are usually analyzed by NYSDOH certified contractor laboratories.

\section{- Data Quality Assurance}

ER Program: As noted above, the offsite contractor laboratories that perform the radiological and chemical analyses for the ER Program are certified by the NYSDOH and participate in the Environmental Laboratory Approval Program (ELAP). The contractor laboratories are required to perform all analytical work in accordance with the ERD Statement of Work for Hazardous Chemical and Radiochemical Analytical Services (BNL, 1998f). In addition, contractor laboratories are audited periodically to verify competence in analytical methodology and implementation of a comprehensive QA program. Field quality control samples are collected. At least five percent of the total numbers of samples collected are duplicated to evaluate the precision of the methods used. Matrix spike/matrix spike duplicates for organic analyses are also performed.

The BNL Groundwater Monitoring Program Quality Assurance Project Plan (BNL, 1999) describes the QA program and the $\mathrm{QC}$ requirements followed during the sitewide groundwater sampling program. Project organizational structure, documentation requirements, sample custody requirements, acceptance criteria, and audit and corrective action provisions, and guidance on the collection of QA/QC samples are also described in this document.

ES Program: Quality assurance procedures for the ES Program are described in BNL Groundwater Monitoring Program Quality Assurance Project Plan (BNL, 1999). Most samples collected for the ES Program are analyzed by BNL's onsite analytical laboratory (ASL). The ASL participates in the DOE Environmental Measurements Laboratory (EML) QA Program and the EPA National Exposure Research Laboratory Performance Evaluation Study. All contractor labs used for groundwater analyses are NYSDOH certified. The BNL ASL and contractor labs have established standard operating procedures to calibrate instruments, analyze samples, and check quality control. Depending upon the analytical method, quality control checks include the analysis of blanks or background concentrations, use of Amersham or National Institute for Standards and Technology (NIST) traceable standards, and analysis of reference standards, spiked samples, and duplicate samples. BNL ASL supervisors validate all analytical results, by assuring data completeness and accuracy. 
- Management of Environmental Data: Environmental data are maintained in a centralized Environmental Information Management System (EIMS). This system consists of an environmental data management system platform linked with a geographic information system (GIS).

- Data Interpretation and Reporting: Results of the BNL ES and ER programs are routinely analyzed and assessed by project managers and/or hydrogeologists. Facility monitoring results are compared to existing baseline and background data and applicable regulatory standards (e.g., NYS DWS, NYS AWQS, and DCGs). Results are reported to the regulatory agencies and general public in a number quarterly, semiannual and annual reports required by DOE Orders, NYS permit requirements, Suffolk County requirements, and CERCLA. Groundwater data are summarized in the annual Site Environmental Report. The discovery of contaminants in groundwater near an active facility requires proper response and notification. As noted previously, BNL has developed a Groundwater Protection Contingency Plan that describes the process used by BNL management to respond to the unexpected detection of contaminants in groundwater.

\section{RESTORATION}

BNL's Environmental Restoration program focuses on remediation of soil and groundwater contamination and preventing additional contamination from migrating off the BNL site. To date, a number of source control measures have been implemented and groundwater remediation systems have been placed into operation or being designed. The performance objectives for groundwater restoration are: 1) minimize contaminant plume growth;2) meet drinking water standards in groundwater for all volatile organic compounds, strontium-90 and tritium; and 3) complete cleanup of the groundwater in Upper Glacial aquifer in thirty years or less.

\subsection{CERCLA Groundwater Treatment Systems}

By 2006, a total of 17 groundwater systems will have been constructed to remediate various plumes onsite and offsite. Figure 11 shows the locations of the current and planned groundwater treatment systems. Nine of the 17 systems have been constructed. This represents about $60 \%$ of the planned groundwater treatment capacity. Seven groundwater treatment systems are currently operating at BNL. Two systems remained in standby mode during 2002 as they have substantially met their goals. Table 1 and the 2002 Groundwater Status Report for BNL provides a summary of each of the systems.

\subsection{Landfill Capping}

The ER Program's Removal Action VI consisted of the capping of three landfills, and the excavation of 55 chemical/glass/animal disposal pits.

- Landfills: In 1995, the Current Landfill was capped using an impermeable geomembrane cover designed to prevent precipitation from entering the landfill, and leaching contaminants into the groundwater. In 1996 and 1997, the Former Landfill and nearby Interim Landfill were covered by similar geomembrane caps. To ensure that the landfill caps remain effective, long-term maintenance and monitoring programs have been established.

- Chemical/Animal Pits and Glass Holes: During the summer of 1997, BNL conducted the bulk excavation and

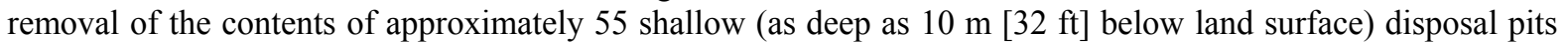
located adjacent to the Former Landfill and Interim Landfill. During the excavation process, waste materials were separated from surrounding soils. Some of the surrounding soils were found to be contaminated with hazardous and/or radioactive materials. The waste materials removed from these pits were sorted and characterized, and then processed according to state and federal guidelines. All wastes and contaminated soils will be disposed of at approved off-site disposal facilities. 


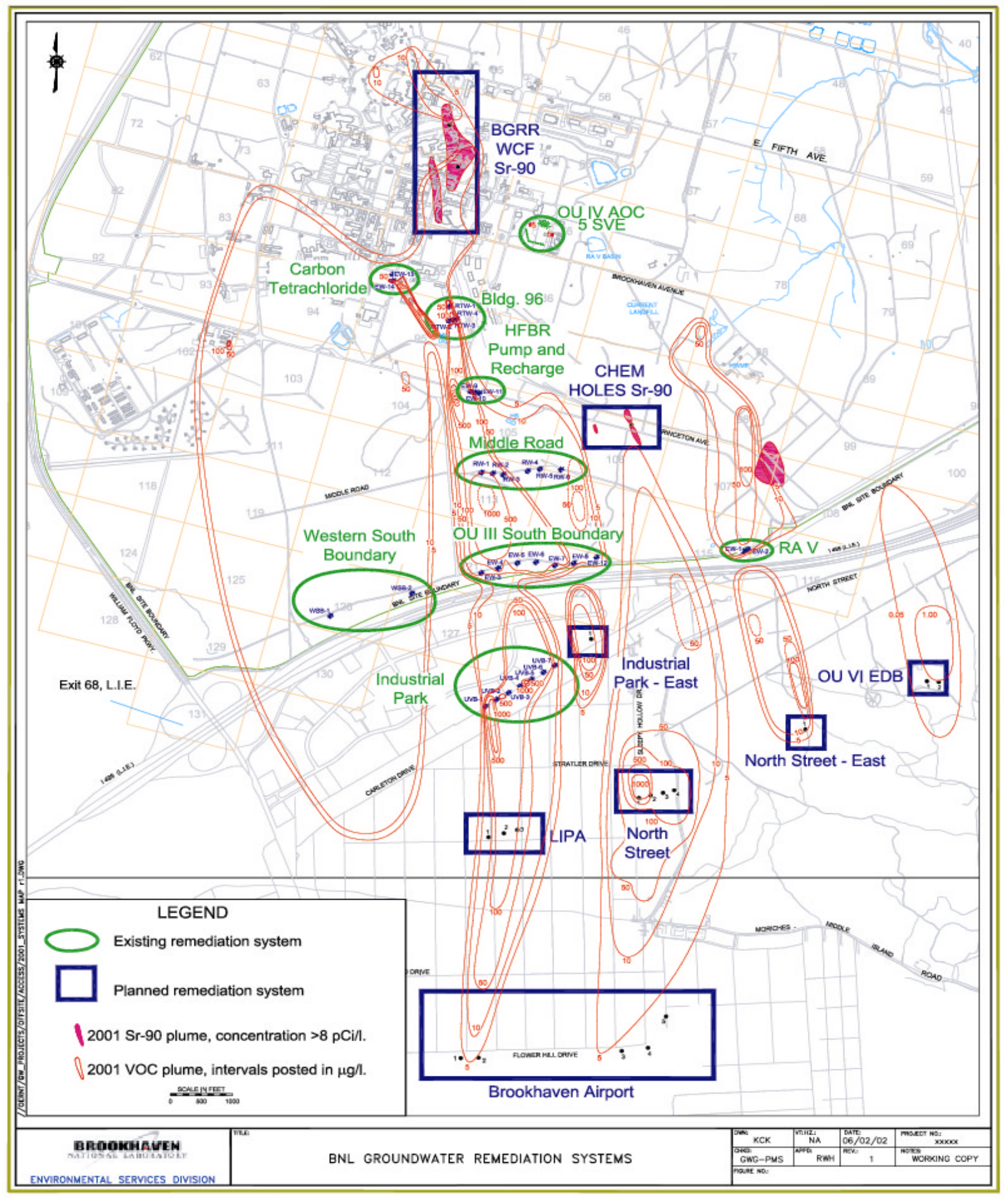

Figure 11. The Location of Active and Planned Groundwater Remediation Systems 
Table 1. Summary of Groundwater Remediation Systems.

\begin{tabular}{|c|c|c|c|c|}
\hline $\begin{array}{c}\text { Operable } \\
\text { Unit }\end{array}$ & System & Technology & Target & Status \\
\hline OU I & RA V & Pump \& treat, air stripper & VOCs & Operational since 1997 \\
\hline \multirow[t]{14}{*}{ OU III } & Chemical Holes & $\begin{array}{l}\text { Pump \& treat, ion } \\
\text { exchange }\end{array}$ & Strontium-90 & $\begin{array}{l}\text { Construction, planned to } \\
\text { be operational in } 2002\end{array}$ \\
\hline & Carbon tetrachloride & $\begin{array}{l}\text { Pump \& treat, carbon } \\
\text { adsorption }\end{array}$ & VOCs & Operational since 1999 \\
\hline & Building 96 & $\begin{array}{l}\text { In-well air stripping, } \\
\text { vapor phase carbon }\end{array}$ & VOCs & Operational since 2001 \\
\hline & South Boundary & Pump \& treat, air stripper & VOCs & Operational since 1997 \\
\hline & Middle Road & Pump \& treat, air stripper & VOCs & Operational since 2001 \\
\hline & Western South Boundary & Pump \& treat, air stripper & VOCs & Operational since 2002 \\
\hline & Industrial Park & $\begin{array}{l}\text { In-well air stripping, } \\
\text { vapor phase carbon }\end{array}$ & VOCs & Operational since 1999 \\
\hline & Industrial Park East & TBD & VOCs & In Design \\
\hline & North Street & $\begin{array}{l}\text { In-well air stripping, } \\
\text { vapor phase carbon }\end{array}$ & VOCs & In Design \\
\hline & North Street East & $\begin{array}{l}\text { In-well air stripping, } \\
\text { vapor phase carbon }\end{array}$ & VOCs & In Design \\
\hline & LIPA & $\begin{array}{l}\text { In-well air stripping, } \\
\text { vapor phase carbon }\end{array}$ & VOCs & In Design \\
\hline & Airport & $\begin{array}{l}\text { In-well air stripping, } \\
\text { vapor phase carbon }\end{array}$ & VOCs & In Design \\
\hline & HFBR tritium & $\begin{array}{l}\text { Pump \& recharge } \\
\text { recirculation }\end{array}$ & Tritium & $\begin{array}{l}\text { Constructed in 1997, in } \\
\text { standby as of } 2001\end{array}$ \\
\hline & BGRR/WCF & To be determined & Strontium-90 & Planning \\
\hline OU IV & AOC 5 & $\begin{array}{l}\text { Air sparging/Soil Vapor } \\
\text { Extraction }\end{array}$ & VOCs & $\begin{array}{l}\text { Constructed in } 1997, \text { in } \\
\text { standby as of } 2001\end{array}$ \\
\hline
\end{tabular}




\subsection{Cesspools and Septic Tanks Removals}

The ER Program's Removal Action III consisted of the removal of 33 cesspools and septic tanks located adjacent to 24 buildings and trailers located throughout the BNL site. These cesspools and septic tanks received industrial waste, which in some cases may have contained radioactive substances. These remedial activities were completed in 1995 and 1996, and are documented in the Removal Action III Close-Out Report (BNL, 1996a).

\subsection{Storage Tank Removals}

- $\quad$ Removal Action I: Three 380,000 liter (100,000 gal.) capacity above ground liquid radioactive waste storage tanks located at the WCF were dismantled and removed in 1994/1995. Wastes generated from these tanks were shipped off-site. The concrete foundations of the tanks were sealed. The contaminated concrete foundations and surrounding soils will be remediated according to the selected remedy in the Operable Unit I Record of Decision.

- Removal Action II: Thirteen underground storage tanks that contained or had contained liquid radioactive waste were excavated, emptied, and removed. Six additional USTs at the WCF that contained radioactive sludges will be removed.

\subsection{Soil Remediation Projects}

A number of soil cleanup projects are planned or have been completed. One of the objectives of these cleanup projects is the protection of groundwater. To ensure effective management and facilitate the cleanup process, similar types of contamination from different Operable Units have been grouped together. Radiologically contaminated soils from areas originally included in OU II/VII, IV, and VI are being cleaned up under OU I because they have similar contaminants. The principal soil contaminants are primarily cesium-137 and strontium-90. Elevated levels of heavy metals are also found in some locations. The chosen cleanup method for radiologically contaminated soils is excavation and disposal to an off-site permitted facility. Approximately 39,000 cubic yards of soils will be removed from BNL. Monitoring will ensure that this remedy is effective. These projects are ongoing and will be completed by July 2005 .

\subsection{Reactor Facility Decontamination and Decommissioning Projects}

The Laboratory's three research reactors, the Brookhaven Graphite Research Reactor, the High Flux Beam Reactor and the Brookhaven Medical Research Reactor, are no longer operating and plans are being made to decontaminate and decommission (D\&D) them. Each of these reactors has historically released contamination to the groundwater. These plumes are being managed as part of the groundwater cleanup projects. The D\&D of these facilities will ensure that further groundwater contamination does not occur.

\section{COMMUNICATIONS}

In March 1998, the BNL Community Involvement program was combined with Public Affairs program creating the Community, Education, Government and Public Affairs (CEGPA) Program. The integration of these two programs has improved BNL's ability to communicate with the community in a consistent, timely and accurate manner. In addition, BNL developed a Community Involvement Policy and Plan. The Policy and Plan were developed with community input and accepted by the DOE and the Laboratory management, as well as stakeholders (see http://www.bnl.gov/community/policy.htm). 
The CERCLA process has driven the majority of communication and community involvement activities related to environmental restoration and protection. The CEGPA Program manages these communication activities for the ER Program. Each remediation project under the ER Program has a community relations plan which identifies scheduled activities for community involvement and input.

Both CERCLA and non-CERCLA groundwater issues fall under the Standards Based Management System procedure entitled "Community Involvement and Laboratory Decision Making." It is the responsibility of all Laboratory Level I, II and project managers to follow this procedure to ensure that stakeholders have a voice in decisions that are important or of interest to them. This procedure is triggered through the Groundwater Protection Contingency Plan and ensures that community involvement and communications plans for groundwater issues are developed and implemented where appropriate. All activities are implemented with the consultation of CEGPA.

It is important to keep the community and regulators informed about groundwater quality near BNL facilities. In response to this need, BNL continues to improve the timeliness and access of groundwater monitoring program results. It is also important to ensure that BNL line managers are aware of the impacts, if any, that their facilities are having on groundwater quality, and enable them to initiate appropriate corrective actions in a timely manner.

\subsection{Technical Reporting}

One of the foundations to the internal and external communications and the community relations activities are technical reports, which summarize, analyze and interpret groundwater data and groundwater protection program indices. These technical reports form the basis of some environmental messages from the Laboratory. The data and data evaluations are presented in technical detail in the Annual Groundwater Status Report, which is submitted to the regulatory agencies and posted on the BNL web. These data are then synthesized into general summaries and presented in the annual Site Environmental Report, which is distributed, to internal and external stakeholders. For active research and support facilities, monitoring reports are prepared semi-annually. These reports are submitted to line managers and posted on the $\mathrm{BNL}$ web. Operational summaries for the groundwater remediation systems are issued quarterly and submitted to the regulators.

\subsection{Groundwater Protection Contingency Plan}

The Laboratory has developed a Groundwater Protection Contingency Plan Subject Area (Lab-wide procedure) to guide technical action and communication in the event of off-normal or unusual groundwater monitoring data are found. This subject area describes specific actions to be taken if validated groundwater monitoring results are above certain offnormal and unusual occurrence trigger levels. The primary goal of this subject area is to ensure that appropriate and timely corrective actions are taken to protect groundwater quality. This subject area provides a formal procedure for ensuring thorough evaluation of the situation and consistency in actions taken (as opposed to treating all results on a case-by-case basis). It includes steps for informing stakeholders about the monitoring results and any follow-up actions.

This subject area focuses on non-routine results that could recommend a dramatically different corrective action, present a real or potential threat to a potable water supply, present a significant threat to the sole source aquifer quality, constitute a regulatory violation, or pose an imminent threat to public health (an unlikely scenario). The subject area also describes actions taken in response to more routine results.

Determining the action levels is complex. They are based on significance, professional judgment, and practical experience at BNL and DOE sites. The action levels take into account a combination of baseline results, regulatory standards, the type of well, well location, the type of contaminant, and analytical measurement uncertainty factors. They also take the type of activity into account; for example, monitoring of known plumes is treated differently from monitoring in areas where no baseline exists.

\subsection{Internal and External Communication Avenues}

The CEGPA Program uses the following avenues for communicating with stakeholders: 
- Brookhaven Bulletin: a publication that is primarily internal, but is also mailed to BNL retirees and key stakeholders.

- Labwide e-mails: a mechanism used to inform and educate employees.

- Cleanupdate: a quarterly newsletter sent to the ER Program's Community Mailing List; it provides updates and information on environmental remediation topics.

- Press Releases/Announcements: a mechanism to inform the media about BNL accomplishments and activities.

- Periodic Mailings to Stakeholders: composed of over two thousand names and addresses of interested individuals and key stakeholders who want to be informed of BNL activities relating to the environment.

- BNL Webpage: information source available to users of the Internet. Each division maintains its own webpage and is linked to the main Lab-wide homepage, which also provides general information about BNL.

- Administrative Record: a complete history of Superfund activities at BNL can be found in this official collection of documents available in three local libraries (Shirley, Longwood and BNL Research Library) and in the USEPA Region II office in New York City. In addition, a complete set of BNL's Site Environmental Reports can be found in these libraries.

\subsection{Community Involvement Activities}

The CEGPA program uses the following outreach and involvement activities to disseminate information and to solicit input from stakeholders who have an interest or who may be affected by activities at the Laboratory:

- Civic Briefings: BNL's Community Involvement staff brief thirteen local civic groups on a regular basis. Messages are prepared based on recent research and environmental activities at the Laboratory.

- Elected Official Briefings: periodic updates are provided to elected officials on issues of interest to their constituencies.

- Summer Sunday Tours: these Sunday open houses offer an opportunity for the general public to visit the Laboratory to learn more about the mission of the Laboratory and to meet face to face with researchers and managers.

- Brookhaven Executive Roundtable: this ad hoc group, composed of regulators, county legislative representatives and key stakeholders, works with the Department of Energy to ensure open communication on issues of interest to this group.

- BNL Community Advisory Council: this group is comprised of key stakeholders, who provide input to the Laboratory management on Laboratory decisions that may affect the community and the general public.

\subsubsection{Internal Groundwater Committee}

BNL established an internal Groundwater Pumping and Recharge Committee. The committee serves to facilitate regular communications on the proper management of groundwater pumpage and recharge activities. Water supply and remediation well pumping and water recharge activities have a significant impact on groundwater flow directions, especially in the central developed area of the BNL site. Stabilizing these flow conditions is of paramount importance for maintaining consistent contaminant plume flow directions. Unstable flow conditions can impact the Laboratory's ability to track groundwater contaminant plumes and monitor facilities, and has the potential to affect the proper operation of groundwater treatment systems. The committee is composed of groundwater project managers and water supply personnel, representatives from appropriate departments/facilities, and personnel from DOE-BAO. 


\subsubsection{External Groundwater Advisory Groups}

BNL routinely interacts with external professional environmental organizations as a means of communicating and obtaining recommendations on future groundwater protection activities. The primary avenue for obtaining feedback on planned or ongoing groundwater protection activities is the State University of New York at Stony Brook's Long Island Groundwater Research Institute (LIGWRI). A member of BNL's Groundwater Protection staff is an active member of the LIGWRI's Advisory Committee. BNL also participates in the DOE Groundwater Working Group, which meets annually to review groundwater protection issues related to DOE operations through out the country.

\subsubsection{Communications with Regulatory Agencies}

Direct communication with regulatory agencies regarding technical issues is the responsibility of DOE/BNL management and technical staff. CEGPA provides support services to management and technical staff to ensure effective communication with regulatory agencies. These support services include presentation skill training, critiques of presentations, coordinating dry-runs, aid in developing presentation materials and handouts, and post-presentation feedback.

\section{Performance Metrics and Systems for Continuous Improvements}

Groundwater protection is an element of the site's Environmental Management System, which requires continuous improvement, and measurement of performance. Several indices have been developed to help evaluate the effectiveness and continuous improvement of groundwater protection at Brookhaven. These include

- the number of off-normal or unusual groundwater monitoring data detected in a year that result in triggering the Groundwater Protection Contingency Plan,

- progress toward meeting cleanup goals as measured via the rate of contaminants removed and extent of VOC plumes as compared to those planned, and

- the number of groundwater samples collected for the environmental restoration program relative to the number planned in the Environmental Management baseline.

To periodically verify that the EMS Program is operating as intended, surveillances and audits are conducted as part of the lab-wide self-assessment program. They are designed to ensure that any nonconformance to ISO 14001 standard or regulatory requirement is identified and addressed. In addition to audits, a management review process is implemented to involve top management in the assessment of the EMS and BNL's environmental performance. An evaluation of the adequacy, suitability, and effectiveness of the EMS Program in achieving BNL's objectives is conducted. As necessary, the need for changes and continual improvement of systems or operations is identified, prioritized and addressed. 


\section{Appendix A - REFERENCES}

Arcadis Geraghty and Miller, Inc. (G\&M), 1999. 1999 Regional Groundwater Model Update, Brookhaven National Laboratory, Upton, New York (July 30, 1999).

Bennett, D.B., Paquette, D.E., Klaus, K, and Dorsch, W.R., 2000. Brookhaven National Laboratory Source Water Assessment for Drinking Water Supply Wells (December 27, 2000). BNL Report 52608

BNL, 1989. Brookhaven National Laboratory Water Utility Master Plan, 1989-2000.

BNL, 1996a. Removal Action III Close-out Report.

BNL, 1996b. Brookhaven National Laboratory Emergency Plan (October 1, 1996; Revision 4). BNL 44350.

BNL, 1997a. RA V Process System Operation and Maintenance Manual (January 1997)

BNL, 1997b. Brookhaven National Laboratory Spill Prevention Control and Countermeasures Plan and Oil Pollution Response Plan, December 1997.

BNL, 1997c. Operable Unit IV Air Sparging/Soil Vapor Extraction Systems Operations, Maintenance, and Monitoring Plan (December 15, 1997).

BNL, 1998a. Operable Unit I Proposed Plan.

BNL, 1998b. Operable Unit IV Remedial Action Work Plan.

BNL, 1998c. Operable Unit IV-Area of Concern 6 Interim Remedy Monitoring Plan (April 9, 1998)

BNL, 1998d. ERD Sitewide Groundwater Monitoring Program, Sampling and Analysis Plan (November 1998).

BNL, 1998f. ERD Statement of Work for Hazardous and Radiochemical Analytical Services (May 4, 1998).

BNL, 1999. BNL Groundwater Monitoring Program, Quality Assurance Project Plan (August 31, 1999).

BNL, 2000, BNL Environmental Monitoring Plan 2000 (March 31, 2000). BNL Report 52584.

BNL, 2001, Site Environmental Report 2000 (September 2001). BNL Report 52626.

BNL, 2002. BNL Environmental Monitoring Plan CY2002 Update. BNL Report 52584 (January 2002)

Briggs, S.L.K., 1998. Brookhaven National Laboratory Environmental Management System, Project Management Plan (October 12, 1998; Revision 0).

Busciolano, R., Monti, J., and Chu, A., 1998. Water Table and Potentiometric-Surface Altitudes of the Upper Glacial, Magothy, and Lloyd Aquifers on Long Island, New York, in March-April, 1997, with a Summary of Hydrogeolgic Conditions. US Geological Survey Water-Resources Investigations Report 98-4019.

CDM Federal Programs (CDM Federal), 1994. OU IV Remedial Investigation/Remedial Action Report (December 7, 1994).

CDM Federal Programs, 1996a. Current Landfill Operations and Maintenance Manual (March 1996). 
CDM Federal Programs, 1996b. Former Landfill Operations and Maintenance Manual (May 1996).

CDM Federal Programs, 1996c. Operable Unit VI Focused Feasibility Study Report (October 1996).

CDM Federal Programs, 1997. Draft Operable Unit I Feasibility Study/Sitewide Radiologically Contaminated Soils (September 8, 1997).

deLaguna, W., 1963. Geology of Brookhaven National Laboratory and Vicinity, Suffolk County, New York: U.S. Geological Survey Bulletin 1156-A, 35 p.

Doriski T.P. and Wilde-Katz, F., 1983, Geology of the 20-Foot Clay in Southern Nassau and Southwestern Suffolk Counties, Long Island, New York: U.S. Geological Survey Water-Resources Investigations Report 82-4056, 17 p.

Faust, G.T., 1963, Physical Properties and Mineralogy of Selected Samples of the Sediments From the Vicinity of the Brookhaven National Laboratory, Long Island, New York: U.S. Geological Survey Bulletin 1156-B, 34 p.

Geraghty and Miller, Inc. (G\&M), 1996. Regional Groundwater Model, Brookhaven National Laboratory, Upton, New York (November 1996).

Goode, G.A., 1998. Brookhaven National Laboratory Process Evaluation Program Plan (June 30, 1998).

Goode, G.A., 2000. Waste Minimization Program Plan for Brookhaven National Laboratory.

International Technologies Corporation (ITC), 1998, Operable Unit II/VII Remedial Investigation/Remedial Alternatives Report (July 1998).

International Technologies Corporation and Geraghty and Miller, Inc. (ITC/G\&M), 1994, Brookhaven National Laboratory - Operable Unit III Remedial Investigation/Feasibility Study Work Plan.

International Technologies Corporation and Geraghty and Miller, Inc., 1998a. Operable Unit V Remedial Investigation Report (May 27, 1998).

International Technologies Corporation and Geraghty and Miller, Inc., 1998b. Draft Operable Unit V Feasibility Study Report (September 30, 1998).

International Technologies Corporation and Geraghty and Miller, Inc., 1998c. Draft Final Operable Unit III Remedial Investigation Report (November 13, 1998)

Jensen, H.M. and Soren, J., 1974, Hydrogeology of Suffolk County, Long Island, New York: U.S. Geological Survey Hydrologic Investigations Atlas HA-501.

Koppelman, L.E. (ed.), 1978, The Long Island Comprehensive Water Treatment Management Plan (Long Island 208 Study): Nassau-Suffolk Regional Planning Board. Hauppauge, N.Y. (July 1978). Volumes I and II.

Long Island Lighting Company (LILCO), 1997. "Long Island Lighting Company Population Estimates.” Paquette, D.E., 1998. Brookhaven National Laboratory, Groundwater Monitoring Improvements Plan for FY 1998 and FY 1999. September 23, 1998.

Royce,B.A., 1997. Interim Report of the BNL Facility Review, Review of Potential Environmental Release Points Priority One Facilities, September 9, 1997. 
Royce, B.A. and Collins, J., 1997. Interim Report of the BNL Facility Review, Review of Potential Environmental Release Points - Priority Two Facilities, December 3, 1997.

Sanok, W.J., 2001. Integrated Pest Management Assessment - Brookhaven National Laboratory. Cornell Cooperative Extension of Suffolk County. August 2001.

Schroeder, G.L., Paquette, D.E., Naidu, J.R., Lee, R.J. and Briggs, S.L.K., 1998. Brookhaven National Laboratory Site Environmental Report for Calendar Year 1996 (January 1998). BNL-52543.

Science Applications International Corporation (SAIC), 1992. Brookhaven National Laboratory Site Baseline Report. Volumes I through IV. January 1992.

Scorca, M.P., Dorsch, W.R., and Paquette, D.E., 1999. Stratigraphy and Hydrologic Conditions at the Brookhaven national Laboratory and Vicinity, Suffolk County, New York, 1994-97: U.S. Geological Survey, Water-Resources Investigations Report 99-4086.

Smolensky, D.A., Buxton, H.T., and Shernoff, P.K., 1989, Hydrogeologic Framework of Long Island, New York: U.S. Geological Survey, Hydrogeologic Investigations Atlas 709, 3 Sheets.

Soren, J. and Simmons, D.L., 1987, Thickness and Hydrogeology of Aquifers and Confining Units Below the Upper Glacial Aquifer on Long Island, New York: U.S. Geological Survey Water Resources Investigations Report 86-4175, 3 Sheets.

Suffolk County Department of Health Services, 1987, Suffolk County Comprehensive Water Resources Management Plan. Division of Environmental Quality. Hauppauge, N.Y. (January 1987). Volumes I and II.

US EPA, 1985. DRASTIC: A Standardized System for Evaluating Ground Water Pollution Potential Using Hydrogeologic Settings. Robert S. Kerr Environmental Research Laboratory, Ada, OK. EPA/600/2-85/018.

US EPA, 1991. Protecting the Nation's Ground Water: EPA's Strategy for the 1990s. EPA21Z-1020, Washington, D.C.

US EPA, 1994. Guidance for the Data Quality Objectives Process (September 1994). US EPA Washington, D.C., EPA QA/G4.

Warren, M.A., deLaguna, W., and Lusczynski, N.J., 1968, Hydrogeology of Brookhaven National Laboratory and Vicinity, Suffolk County, New York: U.S. Geological Survey Bulletin 1156-C, 127 p.

Woodward-Clyde Consultants, 1993. Potable Well Study, Brookhaven National Laboratory, Upton, Long Island, New York 
Appendix B.1

BNL Groundwater Protection Management Program

Major Federal Regulations Related to Groundwater Protection

\begin{tabular}{|c|c|c|}
\hline Regulation & Codification & Description \\
\hline $\begin{array}{l}\text { Comprehensive Environmental } \\
\text { Response, Compensation and Liability } \\
\text { Act (CERCLA) }\end{array}$ & $\begin{array}{l}40 \text { CFR 300, 302, 355, } \\
370\end{array}$ & $\begin{array}{l}\text { CERCLA provides the regulatory framework for the } \\
\text { remediation of releases of hazardous substances and } \\
\text { cleanup of inactive hazardous substance disposal } \\
\text { sites. }\end{array}$ \\
\hline $\begin{array}{l}\text { Federal Insecticide, Fungicide, and } \\
\text { Rodenticide Act (FIFRA) }\end{array}$ & 40 CFR $162-171$ & $\begin{array}{l}\text { FIFRA governs the manufacture and use of } \\
\text { biocides, specifically the use, storage, and disposal } \\
\text { of all pesticides and pesticide containers and } \\
\text { residues. }\end{array}$ \\
\hline $\begin{array}{l}\text { Federal Water Pollution Control Act or } \\
\text { Clean Water Act (CWA) }\end{array}$ & $\begin{array}{l}40 \text { CFR } 109-140,230 \\
231,401,403\end{array}$ & $\begin{array}{l}\text { CWA regulates the quality of waste water } \\
\text { discharged to waters of the United States }\end{array}$ \\
\hline $\begin{array}{l}\text { National Environmental Policy Act } \\
\text { (NEPA) }\end{array}$ & $\begin{array}{l}10 \text { CFR } 1021,40 \text { CFR } \\
1500-1508\end{array}$ & $\begin{array}{l}\text { NEPA establishes a broad national policy to conduct } \\
\text { federal activities in ways that promote the general } \\
\text { welfare and are in harmony with the environment. } \\
\text { NEPA procedures must ensure that environmental } \\
\text { information is available to public officials and } \\
\text { citizens before decisions are made and before } \\
\text { actions are taken. }\end{array}$ \\
\hline $\begin{array}{l}\text { Resource Conservation and Recovery } \\
\text { Act (RCRA) }\end{array}$ & 40 CFR $260-280$ & $\begin{array}{l}\text { RCRA governs the generation, storage, handling, } \\
\text { treatment, and disposal of hazardous waste. } \\
\text { Underground storage tanks and spill release cleanup } \\
\text { are also regulated under this Act. }\end{array}$ \\
\hline $\begin{array}{l}\text { Safe Drinking Water Act (SDWA) of } \\
1974\end{array}$ & 40 CFR 141-149 & $\begin{array}{l}\text { SDWA identifies maximum contaminant levels } \\
\text { (MCLs)governs the distribution and monitoring of } \\
\text { public water supplies. }\end{array}$ \\
\hline $\begin{array}{l}\text { Safe Drinking Water Act } \\
\text { Reauthorization of } 1996\end{array}$ & & $\begin{array}{l}\text { Requires states to establish Source Water } \\
\text { Assessment Programs }\end{array}$ \\
\hline Toxic Substances Control Act (TSCA) & 40 CFR 700-766 & $\begin{array}{l}\text { TSCA regulates the handling, storage and disposal } \\
\text { of wastes containing PCB concentrations greater } \\
\text { than } 50 \text { ppm. }\end{array}$ \\
\hline
\end{tabular}


Appendix B.2

BNL Groundwater Protection Management Program DOE Orders Related to Groundwater Protection

\begin{tabular}{|c|c|c|}
\hline DOE Order/Guidance & Order Number & Description \\
\hline $\begin{array}{l}\text { General Environmental Protection } \\
\text { Program }\end{array}$ & 5400.1 & $\begin{array}{l}\text { Establishes program requirements, authorities, and } \\
\text { responsibilities for DOE operations ensuring compliance with } \\
\text { federal, state, and local environmental protection laws and } \\
\text { regulations, Executive Orders, and internal DOE policies. }\end{array}$ \\
\hline $\begin{array}{l}\text { Hazardous and Radioactive Mixed } \\
\text { Waste Program }\end{array}$ & 5400.3 & $\begin{array}{l}\text { Establishes programs to ensure that hazardous and radioactive } \\
\text { mixed wastes are managed in accordance with AEA and RCRA. }\end{array}$ \\
\hline $\begin{array}{l}\text { Comprehensive Environmental } \\
\text { Response, Compensation, and } \\
\text { Liability Act Requirements }\end{array}$ & 5400.4 & $\begin{array}{l}\text { Establishes DOE CERCLA policies and procedures, including } \\
\text { response to new releases or potential releases of hazardous } \\
\text { substances. }\end{array}$ \\
\hline $\begin{array}{l}\text { Radiation Protection of the Public } \\
\text { and the Environment }\end{array}$ & 5400.5 & $\begin{array}{l}\text { Established radiation standards for the protection of the public in } \\
\text { the vicinity of DOE facilities. The order establishes an annual } \\
\text { dose equivalent from drinking water supplies operated by DOE } \\
\text { at } 4 \text { mrem, and notes that liquid effluent from DOE activities } \\
\text { will not cause public drinking water systems to exceed EPA } \\
\text { MCLs. }\end{array}$ \\
\hline NEPA Compliance Program & $451.1 \mathrm{~A}$ & $\begin{array}{l}\text { Establishes internal DOE responsibilities, authorities and } \\
\text { procedures to implement NEPA. }\end{array}$ \\
\hline Safety Analysis and Review System & 5481.1B & $\begin{array}{l}\text { Establishes procedures for performing safety analyses for DOE } \\
\text { operations, including the identification of hazards, their } \\
\text { elimination and control, assessment of risk, and document } \\
\text { management authorization of the operation. }\end{array}$ \\
\hline $\begin{array}{l}\text { Environmental Safety and Health } \\
\text { Appraisal Program }\end{array}$ & G414.1-1 & $\begin{array}{l}\text { Establishes procedures for the conduct of independent DOE } \\
\text { surveys of environmental programs. }\end{array}$ \\
\hline Radioactive Waste Management & $5820.2 \mathrm{~A}$ & $\begin{array}{l}\text { Established policies and guidelines for managing radioactive and } \\
\text { mixed wastes, and contaminated facilities. }\end{array}$ \\
\hline General Design Criteria & $6430.1 \mathrm{~A}$ & $\begin{array}{l}\text { Provides guidance to ensure that the design and construction of } \\
\text { DOE facilities are adequate for their intended purpose and } \\
\text { consistent with health, safety, security and environmental } \\
\text { protection requirements. }\end{array}$ \\
\hline $\begin{array}{l}\text { Environmental Regulatory Guide for } \\
\text { Radiological Effluent Monitoring } \\
\text { and Environmental Surveillance }\end{array}$ & DOE/EH-0173T & $\begin{array}{l}\text { Provides guidance for conducting effluent monitoring and } \\
\text { groundwater surveillance at DOE sites. }\end{array}$ \\
\hline
\end{tabular}


Appendix B.3

BNL Groundwater Protection Management Program Major New York State Regulations Related to Groundwater Protection

\begin{tabular}{|l|l|l|}
\hline Regulation & Codification & Description \\
\hline NY Public Water Supply Requirements & $\begin{array}{l}\text { 10 NYCRR 5-1 (Part 5 of NYS } \\
\text { Sanitary Code) }\end{array}$ & $\begin{array}{l}\text { Establishes Maximum Contaminant } \\
\text { Levels monitoring and reporting } \\
\text { requirements for potable water supply } \\
\text { systems. }\end{array}$ \\
\hline $\begin{array}{l}\text { NY Water Quality Regulations for } \\
\text { Surface Waters and Groundwaters }\end{array}$ & 6 NYCRR 700-705 & $\begin{array}{l}\text { Establishes NYSDEC Ambient } \\
\text { Groundwater and Surface Water } \\
\text { Quality Standards. }\end{array}$ \\
\hline $\begin{array}{l}\text { NY Hazardous Solid Waste } \\
\text { Management Facilities }\end{array}$ & 6 NYCRR 360 & $\begin{array}{l}\text { Pertains to disposal of solid wastes } \\
\text { disposed of at land disposal facility } \\
\text { (e.g., landfills). }\end{array}$ \\
\hline $\begin{array}{l}\text { NY Hazardous Waste Management } \\
\text { Systems }\end{array}$ & 6 NYCRR 370-376 & $\begin{array}{l}\text { Pertains to hazardous waste } \\
\text { identification, management, and } \\
\text { disposal. }\end{array}$ \\
\hline $\begin{array}{l}\text { NY State Pollutant Discharge } \\
\text { Elimination System (SPDES) }\end{array}$ & 6 NYCRR 750-758 & $\begin{array}{l}\text { Establishes the guidelines for SPDES } \\
\text { related permits, monitoring and } \\
\text { reporting. }\end{array}$ \\
\hline $\begin{array}{l}\text { NY Wild, Scenic and Recreational } \\
\text { Rivers Act }\end{array}$ & Article 15, Title 27 & $\begin{array}{l}\text { Designates the Peconic River at BNL } \\
\text { as a Scenic River, restricts activities } \\
\text { within 800 meters of the river. }\end{array}$ \\
\hline
\end{tabular}

\section{Appendix B.4}

BNL Groundwater Protection Management Program Suffolk County Regulations Related to Groundwater Protection

\begin{tabular}{|l|l|l|}
\hline Regulation & Codification & Description \\
\hline $\begin{array}{l}\text { Suffolk County Article 7 - Water } \\
\text { Pollution Control }\end{array}$ & SCSC Article 7 & $\begin{array}{l}\text { Establishes controls for the discharge } \\
\text { of sewage, industrial and other wastes, } \\
\text { toxic or hazardous materials and storm } \\
\text { water runoff. }\end{array}$ \\
\hline $\begin{array}{l}\text { Suffolk County Article 12 - Toxic and } \\
\text { Hazardous Materials Storage and } \\
\text { Handling Controls }\end{array}$ & SCSC Article 12 & $\begin{array}{l}\text { Establishes toxic and hazardous } \\
\text { materials storage and handling controls } \\
\text { for above ground and below ground } \\
\text { storage facilities. Includes provisions } \\
\text { for installation, inspection and } \\
\text { abandonment of these facilities. }\end{array}$ \\
\hline
\end{tabular}




\section{Appendix C}

\section{Environmental Stewardship Policy}

It is Brookhaven National Laboratory's (BNL) policy to integrate environmental stewardship into all facets of the Laboratory's missions. We will manage our programs in a manner that protects the ecosystem, and employee/public health.

In support of this policy, BNL makes the following commitments:

We are committed to achieving compliance with applicable environmental requirements.

In consideration of the potential impacts of our activities on the environment, we will integrate pollution prevention/waste minimization, resource conservation, and compliance into all of our planning and decision-making. We will adopt cost-effective practices that eliminate, minimize or mitigate environmental impacts.

We will define, prioritize, and aggressively correct and clean up existing environmental problems.

We will work to continually improve our environmental management system and performance. We will establish appropriate environmental objectives and performance indicators to guide these efforts and measure our progress.

We will maintain a positive, proactive, and constructive relationship with our neighbors in the community, regulators, DOE, and our other stakeholders. We will openly communicate with stakeholders on our progress and performance.

All Staff have a role in achieving the policy commitments.

In addition to my annual review of BNL's progress on environmental goals and adherence to this policy, I invite all interested parties to provide me with input on our performance relative to this policy, and the policy itself.

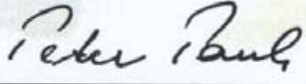

Peter Paul, Interim Director

\section{$4 / 29 / 02$}

Date 